Article

\title{
Brain Cancer Prediction Based on Novel Interpretable Ensemble Gene Selection Algorithm and Classifier
}

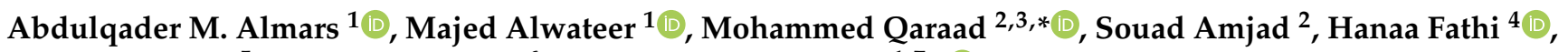 \\ Ayda K. Kelany ${ }^{5}$, Nazar K. Hussein ${ }^{6}$ and Mostafa Elhosseini ${ }^{1,7, *(1)}$
}

1 College of Computer Science and Engineering, Taibah University, Yanbu 46411, Saudi Arabia; Amars@taibahu.edu.sa (A.M.A.); MWATEER@taibahu.edu.sa (M.A.)

2 Department of Computer Science, Faculty of Science, Abdelmalek Essaadi University, Tetouan 93000, Morocco; s.amjad@uae.ac.ma

3 Math and Computer Science Department, Amran University, Amran 891-6162, Yemen

4 Math and Computer Science Department, Menoufia University, Menoufia 32511, Egypt; Hanaa_4_ever@yahoo.com

5 Department of Genomic Medicine, Faculty of Science, Cairo University, Cairo 12613, Egypt; aidakelany@gmail.com

6 Department of Mathematics, College of Computer Sciences and Mathematics, Tikrit University, Tikrit 34001, Iraq; nazar.dikhil@tu.edu.iq

7 Computers Engineering and Control Systems Department, Faculty of Engineering, Mansoura University, Mansoura 35516, Egypt

* Correspondence: m.qaraad@gmail.com (M.Q.); melhosseini@mans.edu.eg (M.E.)

\section{check for} updates

Citation: Almars, A.M.; Alwateer, M.; Qaraad, M.; Amjad, S.; Fathi, H.; Kelany, A.K.; Hussein, N.K.; Elhosseini, M. Brain Cancer Prediction Based on Novel Interpretable Ensemble Gene Selection Algorithm and Classifier. Diagnostics 2021, 11, 1936. https://doi.org/10.3390/ diagnostics11101936

Academic Editor: Hidehiko Okazawa

Received: 23 August 2021

Accepted: 13 October 2021

Published: 19 October 2021

Publisher's Note: MDPI stays neutral with regard to jurisdictional claims in published maps and institutional affiliations.

Copyright: (C) 2021 by the authors. Licensee MDPI, Basel, Switzerland. This article is an open access article distributed under the terms and conditions of the Creative Commons Attribution (CC BY) license (https:// creativecommons.org/licenses/by/ $4.0 /)$.

\begin{abstract}
The growth of abnormal cells in the brain causes human brain tumors. Identifying the type of tumor is crucial for the prognosis and treatment of the patient. Data from cancer microarrays typically include fewer samples with many gene expression levels as features, reflecting the curse of dimensionality and making classifying data from microarrays challenging. In most of the examined studies, cancer classification (Malignant and benign) accuracy was examined without disclosing biological information related to the classification process. A new approach was proposed to bridge the gap between cancer classification and the interpretation of the biological studies of the genes implicated in cancer. This study aims to develop a new hybrid model for cancer classification (by using feature selection mRMRe as a key step to improve the performance of classification methods and a distributed hyperparameter optimization for gradient boosting ensemble methods). To evaluate the proposed method, NB, RF, and SVM classifiers have been chosen. In terms of the AUC, sensitivity, and specificity, the optimized CatBoost classifier performed better than the optimized XGBoost in cross-validation 5, 6, 8, and 10. With an accuracy of $0.91 \pm 0.12$, the optimized CatBoost classifier is more accurate than the CatBoost classifier without optimization, which is $0.81 \pm 0.24$. By using hybrid algorithms, SVM, RF, and NB automatically become more accurate. Furthermore, in terms of accuracy, SVM and RF $(0.97 \pm 0.08)$ achieve equivalent and higher classification accuracy than NB $(0.91 \pm 0.12)$. The findings of relevant biomedical studies confirm the findings of the selected genes.
\end{abstract}

Keywords: gene expression data; brain cancer; classification; ensemble methods; hyperparameter optimization; feature selection; gene selection

\section{Introduction}

Brain cancer is the leading cause of death in women under the age of 20 and men under 40 [1,2]. Moreover, the prevalence of malignant brain tumors is rising [3], severely impacting society and human health [4]. Primary brain tumors arise from the brain cells themselves, while secondary brain tumors arise from malignant cells outside of the brain and spread there [5]. According to studies, brain tumors are extremely heterogeneous, posing a major challenge for classification, segmentation, diagnosis, and prognosis [6]. 
Microarray-based gene expression profiling has proven useful for cancer detection, prognosis, and treatment [7]. In addition, in recent years, DNA microarray technology has significantly impacted the information that we have bout what causes cancer $[8,9]$.

Cancer microarray data typically contain a small number of samples with many gene expression levels as features, which leads to the curse of dimensionality, making the classification of microarray data a difficult task. The bioinformatics community uses a variety of approaches to classify microarray data using machine learning systems. Most of the examined studies on cancer classification using microarray data sets take cancer classification accuracy into account without disclosing any biological information of the cancer classification process. Few studies have investigated the biological interpretation of microarray data sets in addition to the model classification accuracy. This research aims to bridge the gap between cancer classification and biological interpretation by improving accuracy performance, and the selected significant genes agree with the findings of relevant biomedical studies.

This paper proposes a hybrid model based on three different machine learning techniques, including the commonly used ensemble classification methods of gradient boosting [10], an extremely efficient ML algorithm that produces a strong learner in the form of an ensemble of weak learners/models. Furthermore, to optimize the hyperparameters of machine learning algorithms, distributed hyperparameter optimization [11] is one of the most efficient methods (per function evaluation) that is utilized for parameter optimization. Furthermore, minimum redundancy maximum relevance (mrmr) [12] is a particularly fast feature selection method that can be used to find a set of relevant and complementary features. Our model was assessed using three different machine learning classifiers: random forest (RF), naive Bayes (NB), and support vector machines (SVM).

The experiments show that the proposed model substantially reduces the number of genes required for classification and improves classifier accuracy. Additionally, the proposed hybrid model's selected genes (features) are biologically interpreted, and the biological interpretation coincides with the findings of relevant biomedical studies.

The main contributions of this work are:

1. The proposal of a novel ensemble classifier to ensure that the genes selected in our model are biologically interpreted. On top of that, the results are also satisfactory and in line with pertinent biomedical studies.

2. The identification of relevant and non-redundant genes for the biological context by ensemble mRMRs, allowing for enhanced biological interpretations.

3. The analysis of a brain cancer microarray dataset on high-dimensional data using Catboost and XGboost.

4. The optimization of the hyperparameters of the two classifiers using the hyperboot optimizer.

5. The outperformance of Catboost compared to XGboost with regard to the AUC, sensitivity, specificity, and accuracy.

The remainder of the paper is structured as follows: Section 2 briefly reviews related work, while Section 3 reviews some background research that was used in the proposed methodology. Section 4 explains the proposed model, while Section 5 discusses the experimental design, findings, and discussion. Finally, Section 6 concludes the whole paper by summarizing the contributions of the paper.

\section{Literature Review}

In recent years, multiple pieces of research have used a wide range of machine learning methods for the classification, diagnosis, and treatment of cancer disease. BU-Net was developed by Rehman [13] and others to segment and classify brain tumor regions. Their model with a modified encoder-decoder architecture was proposed for segmenting brain tumors. Tests of the proposed BU-Net architecture were conducted on BraTS 2017 and 2018. BU-Net proved to be a significant improvement over the baseline U-Net architecture and other existing segmentation models. Radiology mMRI imaging sub-regions can affect 
tumor localization, so researchers suggested a deep learning method [14] that considers the uncertainty of the tumor location. Then, they classified the tumor segments into subtypes using a conventional 3D convolutional neural network (CNN). Performance was measured by widely used measures such as the dice score coefficient, the Hausdorff distance at percentile 95 (HD95), classification accuracy, and mean square error. According to the findings, the suggested method can accurately segment tumors and predict survival rates.

Bashir et al. [15] used a fusion of five classifiers: naive Bayes, decision tree using Gini index, decision tree using information gain, support vector machines, and memorybased learner, to diagnose breast cancer. The weighted vote-based ensemble technique was then used to make the final prediction. Several preprocessing and feature selection methods were also used on four breast cancer datasets to improve the prediction accuracy. The proposed ensemble classifiers achieved remarkable results, with average accuracy, precision, and recall of $85.23 \%, 86.18 \%$, and $76.68 \%$. However, small datasets were used to test the performance of the model. Applying the proposed ensemble on a large dataset with many features may lead to computational instability.

To overcome the dimensionality problem, Kumar et al. [16] introduced the ANOVA, Kruskal-Wallis, and Friedman tests as examples of statistical methods (tests) based on MapReduce to select relevant features. The MapReduce-based proximal support vector machine (mrPSVM) classifier was also applied to classify the microarray data after feature selection. The Hadoop framework was used to implement these algorithms. Using the microarray datasets of different dimensions, a comparative study of these feature selection methodologies was performed. The experimental results showed that an ensemble of the mrPSVM classifier and various feature selection methods produced higher accuracy than other models. Thus, the proposed model successfully handled big data, but it could only interpret biological microarray data. Finally, a two-phase hybrid model for cancer classification was proposed (iBPSO) by Jain et al. [17] that consisted of correlation-based feature selection (CFS) and improved-binary particle swarm optimization. The proposed model uses the naive Bayes classifier to select a low-dimensional collection of prognostic genes to identify biological samples of binary and multi-class cancers. The model was evaluated and tested on eleven benchmark microarray datasets. The findings of the experiments showed that the model outperformed several well-known approaches in terms of classification accuracy and the number of selected genes.

Pradana et al. [18] introduce an approach that used binary particle swarm optimization (BPSO) as a feature selection and C4.5 decision tree as a classifier to investigate cancer diagnosis based on microarray data. The decision tree rule model requires discretization, which is accomplished by the use of K-Means. Applying BPSO and decision tree showed that the model could successfully find the most significant features and increase the accuracy. The model achieved accuracies of 54\% and 99\%, respectively, for C4.5 and BPSO. Shukla et al. [19] also proposed a new filter-based gene selection approachto identify highly important genes in microarray gene expression datasets. The proposed approach was evaluated using well-known classification techniques such as support vector machine, naive Bayes, $k$-nearest neighbor, and decision tree on the diffuse large B cell lymphoma (DLBCL) dataset. Experiments confirmed that the proposed model could successfully compete, with excellent predictions concerning the accuracy, precision, sensitivity, Fmeasure, and ROC value.

Sampathkumar et al. [20] developed a novel cuckoo search with a crossover algorithm that could accurately classify a variety of cancer subtypes. The model was tested on benchmark cancer gene expression, and the results show that CSC outperformed CS and other well-known methods. Kilicarslan et al. [21] used the relief algorithm for dimension reduction and feature ranking. The most important features were then used by support vector machines (SVM) and convolutional neural networks (CNN) [22] for prediction. The experimental results show that the proposed approach could improve the accuracy of SVM and CNN classification methods. Finally, Lee et al. [23] suggested a novel multivariate feature ranking approach to increase gene selection efficiency in microarray data. The 
proposed method created a new feature ranking method by embedding the formal concept of relevance into a Markov blanket (MB). The results show that the model performs well in high-dimensional microarray data classification.

Given all that has been mentioned so far, all of the algorithms listed above address two major issues: brain cancer classifiers and the curse of dimensionality. However, there is no biological interpretation of the microarray data set discussed in the literature. To the best of our knowledge, this paper is the first paper to provide a consolidated biological interpretation of the results of the proposed work. Table 1 summarizes some of the previous research methods for microarray cancer classification to conclude and review related work.

Table 1. Review of previous studies on the cancer microarray data classification.

\begin{tabular}{|c|c|c|c|c|c|}
\hline Author & Method & Remark & Limitations & Dataset & \\
\hline $\begin{array}{c}\text { Bashir, S., Qamar, U., and } \\
\text { Khan, F. H. (2015) [15]. }\end{array}$ & $\begin{array}{c}\text { (Naïve } \\
\text { Bayes, } \\
\text { DT-Gini, } \\
\text { DT-IG, MBL } \\
\text { and SVM) }\end{array}$ & $\begin{array}{l}\text { A weighted vote- } \\
\text { based ensemble } \\
\text { fusion of heteroge- } \\
\text { neous classifiers was } \\
\text { introduced for dy- } \\
\text { namic breast cancer } \\
\text { diagnosis. }\end{array}$ & $\begin{array}{l}\text { - } \text { Small datasets } \\
\text { were used to } \\
\text { test the perfor- } \\
\text { mance of the } \\
\text { model. } \\
\text { - A small set of } \\
\text { features are } \\
\text { used to test } \\
\text { the proposed } \\
\text { model. }\end{array}$ & $\begin{array}{ll}- & \text { UCI [24] } \\
- & \text { Wisconsin } \\
& {[25]}\end{array}$ & Clinical \\
\hline
\end{tabular}

- Data on microarrays are classified using proximal support vector machines

Kumar, M., and Rath, S. K. (2015) [16].

(MrPSVM) (mrPSVMs) based on MapReduce.

- Large-scale results were managed using Hadoop.
- No biological interpretation of the microarray data set was discussed.
Kent Ridge Biomedical Data Set Repository [26]

National center of Biotechnology Information (NCBI GEO) [27]
Jain, I., Jain, V. K., and Jain, R. $\quad$ (CFS) and (2018) [17]
- Hybrid feature selection is proposed for gene selection and cancer classification that combines correlation-based and binary particle swarm optimization.

- Tested on eleven benchmark microarray datasets
Biological information on the cancer classification process is not discussed.
- Kent Ridge Biomedical Data Set Repository [28]

\section{By using filtering methods, some important features may not be included. There is no \\ Kent Ridge Bio- medical Data Set Repository [29]} interpretation of the results. 
Table 1. Cont

\begin{tabular}{|c|c|c|c|c|}
\hline Author & Method & Remark & Limitations & Dataset \\
\hline $\begin{array}{l}\text { Shukla, A. K., and Tripathi, D. } \\
\text { (2020) [19] }\end{array}$ & $\begin{array}{c}\text { Spearman's } \\
\text { Correlation } \\
\text { (SC) and } \\
\text { distributed } \\
\text { FS }\end{array}$ & $\begin{array}{l}\text { - Introduced a new } \\
\text { filter-based method } \\
\text { for gene selection } \\
\text { that can select the } \\
\text { highly relevant genes } \\
\text { for distinguishing } \\
\text { tissues from the gene } \\
\text { expression dataset }\end{array}$ & $\begin{array}{l}\text { Biological } \\
\text { informa- } \\
\text { tion is not } \\
\text { addressed. }\end{array}$ & - $\quad$ DLBCL $[30,31]$ \\
\hline
\end{tabular}

\section{Materials and Methods}

This section discusses ensemble classification and how to set the hyperparameter values and the minimum redundancy maximum relevance (mRMR) feature selection. The three main components of the proposed method are ensemble classification, hyperparameter optimization, and minimum redundancy maximum relevance (mRMR). First, the ensemble methods use multiple learning algorithms to achieve better predictive performance than if they were used by themselves. Secondly, we have hyperparameter optimization, in which the parameters of the classifier are tuned to find the optimal setting. The third one is minimum redundancy maximum relevance (mRMR), which is a filter-type feature selection method that obtains the best feature set by minimizing the similarities between features and classified variables and by maximizing their correlations

\subsection{Ensemble Classification}

Ensemble learning methods use multiple machine learning algorithms to generate weak predictive results based on the features extracted from various data projections. Following this, the results are fused with various voting mechanisms to achieve better results than any constituent algorithm alone [32,33]. Figure 1 depicts the basic concept of a typical ensemble classification model [34], which consists of two steps: (1) generating classification results using multiple weak classifiers and (2) integrating multiple results into a consistency function to obtain the results with voting schemes.

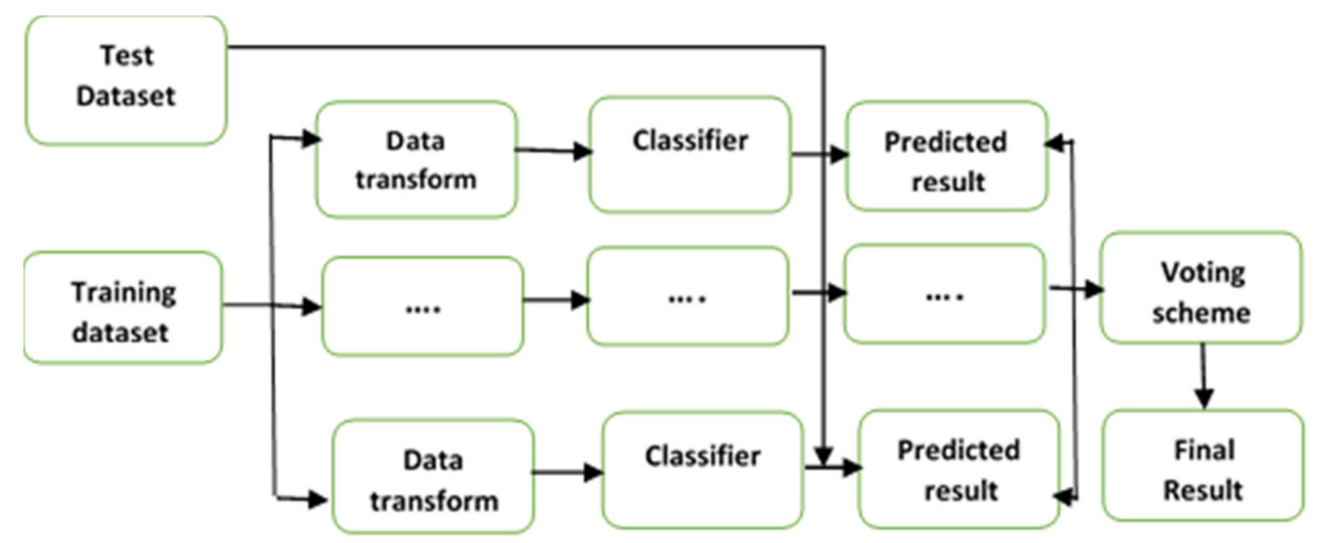

Figure 1. The ensemble classification framework.

The gradient boosting method, which constructs the solution stagewise and solves the overfitting problem by optimizing the loss functions, is one of the most commonly used ensemble classification methods. The main concept of a gradient boosting model is depicted in Figure 2. 


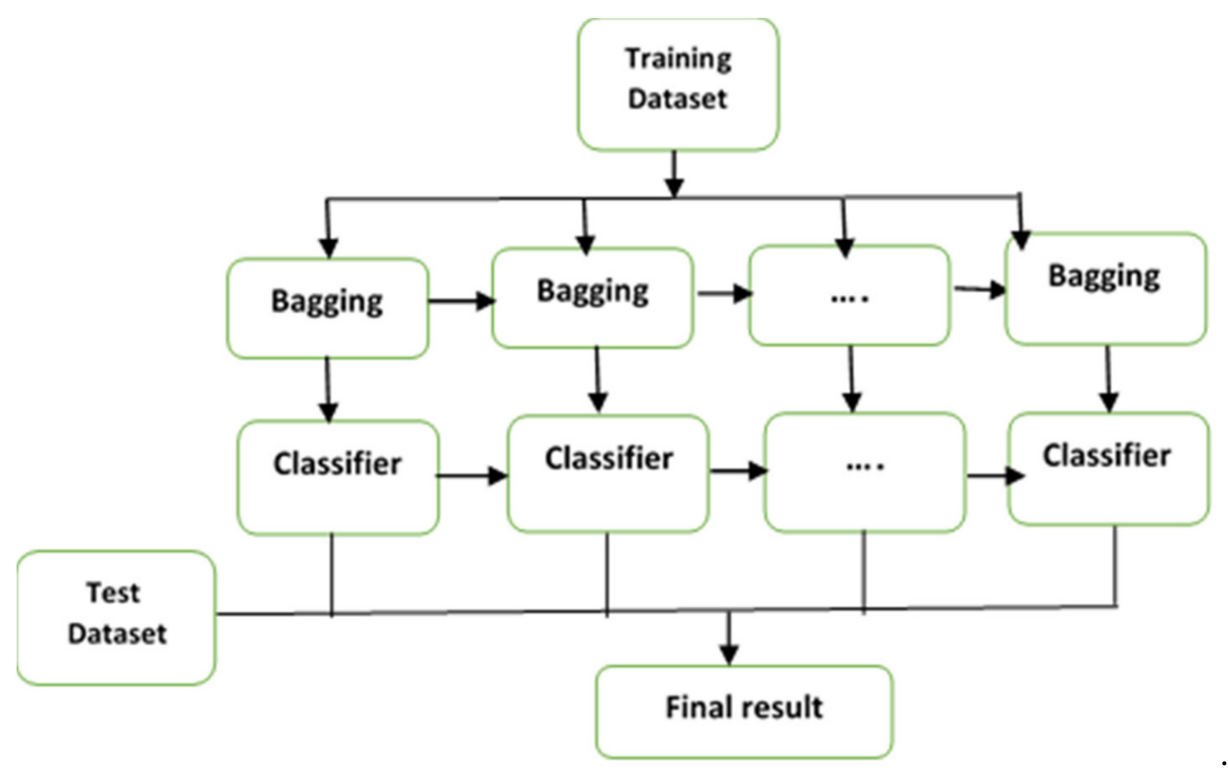

Figure 2. The gradient boosting framework.

XGBoost is an efficient gradient-boosted decision tree algorithm [35]. Gradient boosting is a technique introduced by XGB. The new models are fitted to residuals from previous models, and the combined results are minimized using gradient descent. Yandex released CatBoost [36] in 2017 and demonstrated that it was faster in terms of prediction making, that it was more accurate, and that it was easier to use for categorical data across a series of GBDT tasks based on their benchmark. As a better gradient boosting algorithm, Catboost introduces ordered boosting. Table 2 illustrates the two gradient boosting algorithms.

Table 2. XGBoost and CatBoost classifiers.

\begin{tabular}{|c|c|c|c|}
\hline & $\begin{array}{c}\text { Base } \\
\text { Classifiers }\end{array}$ & $\begin{array}{l}\text { Ways to Prevent } \\
\text { Overfitting }\end{array}$ & $\begin{array}{c}\text { The Loss Function for Binary } \\
\text { Classification }\end{array}$ \\
\hline XGBoost & Regression trees & $\begin{array}{l}\text { - Row Subsampling } \\
\text { 口 } \\
\text { - } \text { Chrinkage parameter } \\
\text { - } \text { Column subsampling } \\
\text { Regularization term in the } \\
\text { objective function }\end{array}$ & $\begin{array}{c}L=y \log (p(x))+ \\
(1-y) \log (1-p(x)), p(\mathbf{x})= \\
\frac{1}{1+\exp (-F(\mathbf{x}))}\end{array}$ \\
\hline CatBoost & Classification trees & $\begin{array}{ll}\text { 口 } & \text { Row Subsampling } \\
\text { 口 } & \text { Shrinkage parameter } \\
\text { 口 } & \text { Column subsampling }\end{array}$ & $L_{i}=-y_{i} \log p_{i}^{\wedge}\left(1-y_{i}\right) \log \left(1-p_{i}^{\wedge}\right)$ \\
\hline
\end{tabular}

\subsection{Hyperparameter Optimization}

Hyperopt is a Python library that implements sequential model-based optimization (SMBO) [9]. Hyperopt provides algorithms and software infrastructure to conduct hyperparameter optimization for machine learning algorithms. Hyperopt has an optimization interface that separates a configuration space from an evaluation function that assigns real-valued loss values to points in the configuration space. It works by treating the search of hyperparameters as an optimization task.

Hyperparameter search spaces are typically large multi-dimensional spaces. Hyperopt outperforms grid and random searches, particularly as the search space grows. Within the framework of our proposed model, Hyperopt is used to optimize the settings for 
the XGBoost and CatBoost hyperparameters. It aims to identify the optimal genes for microarray data analysis and to improve the classification of cancer microarrays.

\subsection{Minimum Redundancy Maximum Relevance (mRMR) for Feature Selection}

Minimum redundancy maximum relevance (mRMR) is a filter-type feature selection method that obtains the best feature set by maximizing the correlation between the features and the classified variables and by minimizing the correlation between features. The classic function enables the collection of appropriate and non-redundant features with ease [37]. In set $S$, the maximally important and minimally redundant gene $i^{*}$ is given by:

$$
i^{*}=\operatorname{argmaX}_{i} \in S \frac{R_{S}}{Q_{S, i}}
$$

Ensemble (mRMR) feature selection implements two ensemble approaches: exhaustive and bootstrap ensemble mRMR. The exhaustive variant of the mRMR heuristic extends it by starting multiple feature selection procedures, with the $k>1$ being the most relevant feature. Following that, $k m R M R$ solutions are generated in parallel, with the first selected feature being guaranteed to be different. The bootstrap variant resamples the original dataset (with replacement) to generate $k$ bootstraps. Finally, classical mRMR feature selection is performed in parallel for each bootstrapped dataset, resulting in $k$ mRMR solutions.

\section{The Proposed Hybrid Model}

This section describes the model (as shown in Figure 3) used for brain cancer classification. The Hyperopt optimizer is used to estimate the optimal values of the CatBoost hyperparameters.

The main process of the model can be defined as:

(i) Preprocessing the dataset (brain cancer microarray). This step is vital to

a. Avoid features in greater numeric ranges dominating those in smaller ranges;

b. Avoid numerical difficulties during calculation;

c. Ensure that each feature is scaled to the range [0,1].

(ii) The data were partitioned into two sets: The training set is used for the training. The testing set is used to test final model 3, initializing CatBoost with specific solution parameters. Table 3 describes the parameter initialization of the classifiers

(iii) CatBoost is used as a feature selector with 8 -fold cross-validations (8 cross-validations of different levels of importance for every gene index). CatBoost calculates the means for each fold.

(iv) By setting a threshold, irrelevant features are then removed. Suppose the score of a gene is above the threshold. In that case, the gene will be selected (as seen in Appendix A, the optimal threshold that offers the maximum accuracy is: 0.84). The genes are shuffled, and unique genes are kept.

(v) The importance value of each gene is registered using a voting process. For example, the gene with index 1 in fold 0 receives an importance value of 1 if the same gene is present in the next fold; then, the gene importance is +1 , and so on, for all of the 8 -fold cross-validations. After this was applied, voting is conducted 50 genes (six of the filtered genes are genes with an importance $>8$. 


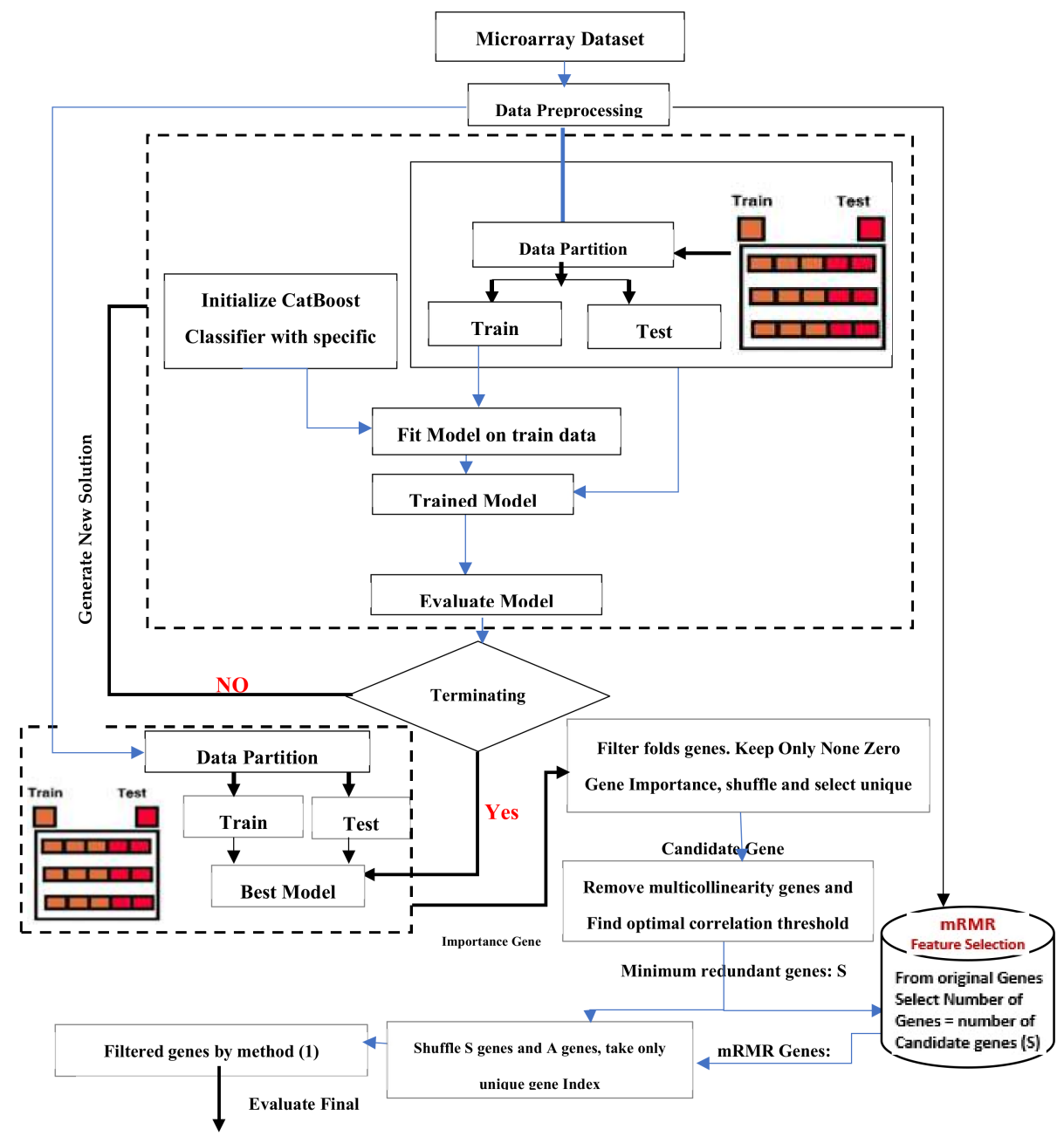

Figure 3. The proposed hybrid model.

Table 3. Parameter initialization.

\begin{tabular}{cccc}
\hline \multicolumn{2}{c}{ XGBoost Classifier } & \multicolumn{2}{c}{ CatBoost Classifier } \\
\hline Hyperparameters & Range & Hyperparameters & Range \\
\hline iterations & {$[1,500]$} & n_estimators & {$[50,900]$} \\
\hline depth & {$[1,16]$} & max_depth & {$[1,12]$} \\
\hline subsample & {$[0.5,1]$} & m_child_weight & {$[1,6]$} \\
\hline rsm & {$[0.75,1.0]$} & gamma & {$[0.5,1]$} \\
\hline learning_rate & {$[-3.0,-0.7]$} & subsample & {$[0.5,1]$} \\
\hline 12_leaf_reg & {$[1,10]$} & learning_rate & {$[\log (0.001), \log (0.3)]$} \\
\hline random_strength & {$\left[1 \times 10^{-9}, 10\right]$} & colsample_bytree & {$[0.5,1]$} \\
\hline bagging_temperature & {$[0.0,1.0]$} & & \\
\hline scale_pos_weight & {$[0.01,1.0]$} & & \\
\hline
\end{tabular}

\section{Results and Discussion}

In this section, we present the findings of the various experiments to judge the performance of the proposed hybrid model. A PC with the following features was used to test the proposed hybrid model: Intel(R) Core (TM) i5-7500 CPU with a 32-bit operating system, 4 GB RAM, and the Windows 7 operating system as well as the NumPy, SciPy, Pandas, Keras, and Matplotlib frameworks and Python 2.7 programming language. 


\subsection{Datasets}

Molecular profiles from 28 patient samples were analyzed (data set A: medulloblastomas, CNS AT/RTs, renal and extrarenal rhabdoid tumors, supratentorial PNETs, and normal human cerebella). In addition, an analysis of frozen specimen RNA with oligonucleotide microarrays containing probes for 1070 genes was conducted. Gene expression data are available in the Supplementary Information [30].

$k$-fold tests were used in the majority of previous experiments. $k$-fold verification works to find crossed validity by randomly dividing data into $\mathrm{k}$ subsets of (approximately) equal size and $k$-times. As a result, it will run several times, with one subset serving as a test group and the other subset, $k-1$, serving as a training group (see Figure 3). The mean of the $k$-fold results can then be averaged to present a single evaluation. In our experiments, we used eight-fold cross-validation to evaluate the outcomes of the proposed hybrid model, and the results are represented as an average standard deviation. Furthermore, the total number of iterations in all of the experiments was 30. In our experiments, we used three evaluation methods [38]: specificity (Spec.), sensitivity (Sen.), and area under the curve (AUC) (AUC).

Sensitivity, as calculated by $S=T P /(T P+F N)$, is the likelihood that a diseased person is recognized as diseased through the test, where $\mathrm{TN}$ is the true negatives number, and TP is the true positives number, and $\mathrm{N}$ is the false negative. Specificity is the likelihood that a person without the illness is defined by the ((TEST) as non-diseased (or healthy). It is described as $T N R=(T N) /(T N+F P)$, where FP implies the number of false positives, and $\mathrm{TN}$ is the number of true negatives. The AUC shows the area under the receiver operating characteristics (ROC) curve, calculated as $A U C=(1+T P R-F P R) / 2$.

\subsection{Experiment 1: Comparing Performance of Optimized (CatBoost and XGBoost) with the Proposed Hybrid Model}

This experiment compares optimized (CatBoost and XGBoost) classifiers in the proposed hybrid model to achieve the best hyperparameter of the two classifiers. The Hyperopt optimizer is used. Table 3 lists the hyperparameters settings values of XGBoost and CatBoost and the range of each parameter. The experimental results are shown in Table 4 and Figures 4 and 5 . The most striking results are better results for the optimized CatBoost classifier than the optimized XGBoost with cross-validation 5, 6, 8, and 10 in the AUC, Sen, and Spec results.

Table 4. Comparing performance of optimized (XGboost and Catboost) in terms of AUC, Sen., and Spec.

\begin{tabular}{|c|c|c|c|c|c|c|}
\hline \multirow{2}{*}{$\begin{array}{c}\text { Cross } \\
\text { Validation } \\
\text { (CV) }\end{array}$} & \multicolumn{3}{|c|}{ XGBoost Classifier } & \multicolumn{3}{|c|}{ CatBoost Classifier } \\
\hline & AUC & Sen & Spec & AUC & Sen & Spec \\
\hline $\mathrm{Cv}=5$ & $\begin{array}{c}0.80 \pm \\
0.16\end{array}$ & $\begin{array}{c}0.80 \pm \\
0.16\end{array}$ & $0.80 \pm 0.16$ & $0.87 \pm 0.07$ & $0.80 \pm 0.16$ & $0.93 \pm 0.13$ \\
\hline$C v=6$ & $\begin{array}{c}0.83 \pm \\
0.13\end{array}$ & $\begin{array}{c}0.75 \pm \\
0.26\end{array}$ & $0.93 \pm 0.19$ & $0.89 \pm 0.11$ & $0.86 \pm 0.20$ & $0.92 \pm 0.19$ \\
\hline $\mathrm{Cv}=8$ & $\begin{array}{c}0.81 \pm \\
0.16\end{array}$ & $\begin{array}{c}0.81 \pm \\
0.24\end{array}$ & $0.81 \pm 0.24$ & $0.91 \pm 0.12$ & $0.88 \pm 0.21$ & $0.93 \pm 0.16$ \\
\hline $\mathrm{Cv}=10$ & $\begin{array}{c}0.75 \pm \\
0.29\end{array}$ & $\begin{array}{c}0.75 \pm \\
0.33\end{array}$ & $0.75 \pm 0.40$ & $0.88 \pm 0.17$ & $0.85 \pm 0.23$ & $0.90 \pm 0.03$ \\
\hline
\end{tabular}

From the data in Figures 4 and 5, it is apparent that CatBoost classifier has the best accuracy, $0.97 \pm 0.08$, with 8-fold cross-validation and the best $A U C=0.97 \pm 0.08$, Sen $=0.94 \pm 0.17$, and Spec $=1.00 \pm 0.00$ compared to the XGBoost classifier, which had an accuracy of $0.80 \pm 0.21$, and where the $A U C=0.80 \pm 0.21$, Sen $=0.80 \pm 0.21$, and $\mathrm{Spec}=0.80 \pm 0.21$. All in all, these results point to CatBoost having a higher performance than XGBoost in the hybrid model we developed. Table 5 shows the training vs. testing performance with 8 -fold cross-validation in 28 samples. 


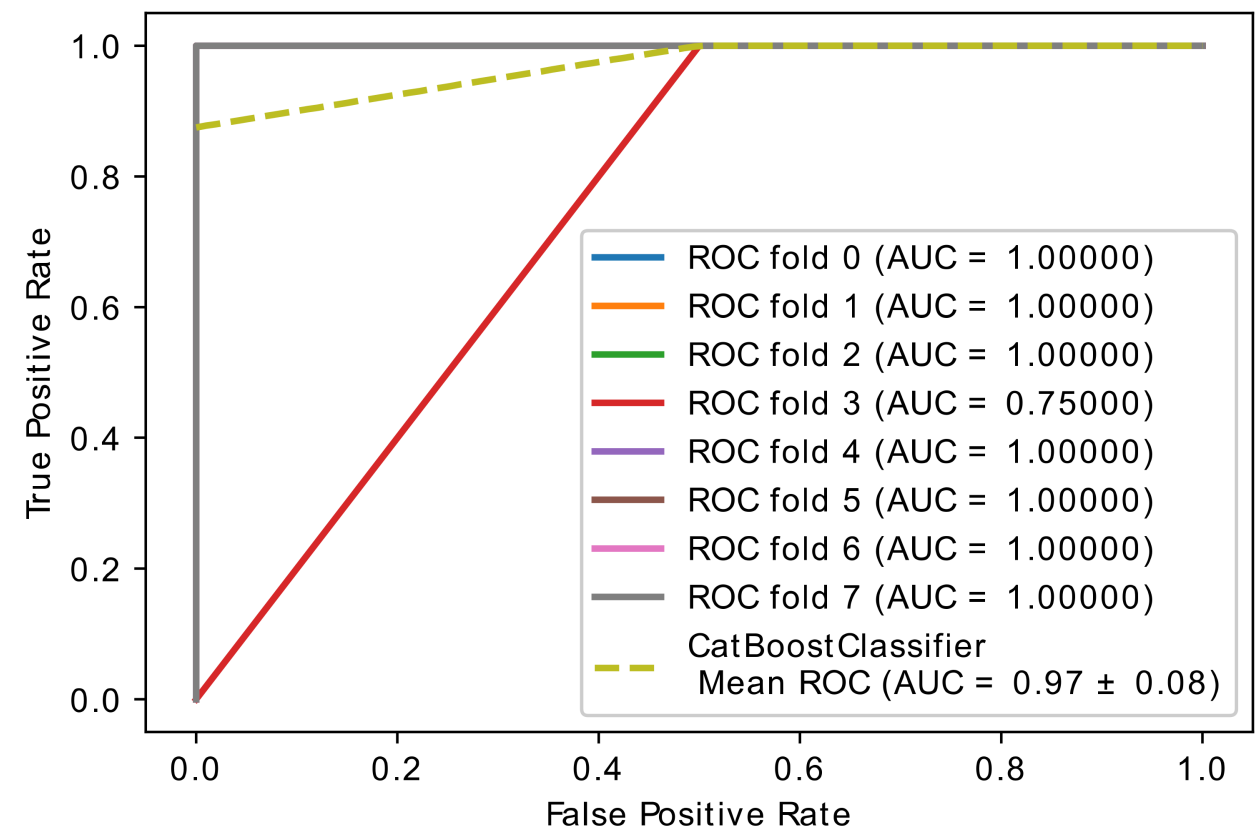

Figure 4. Accuracy curve obtained using the hybrid model with optimized CatBoost classifier.

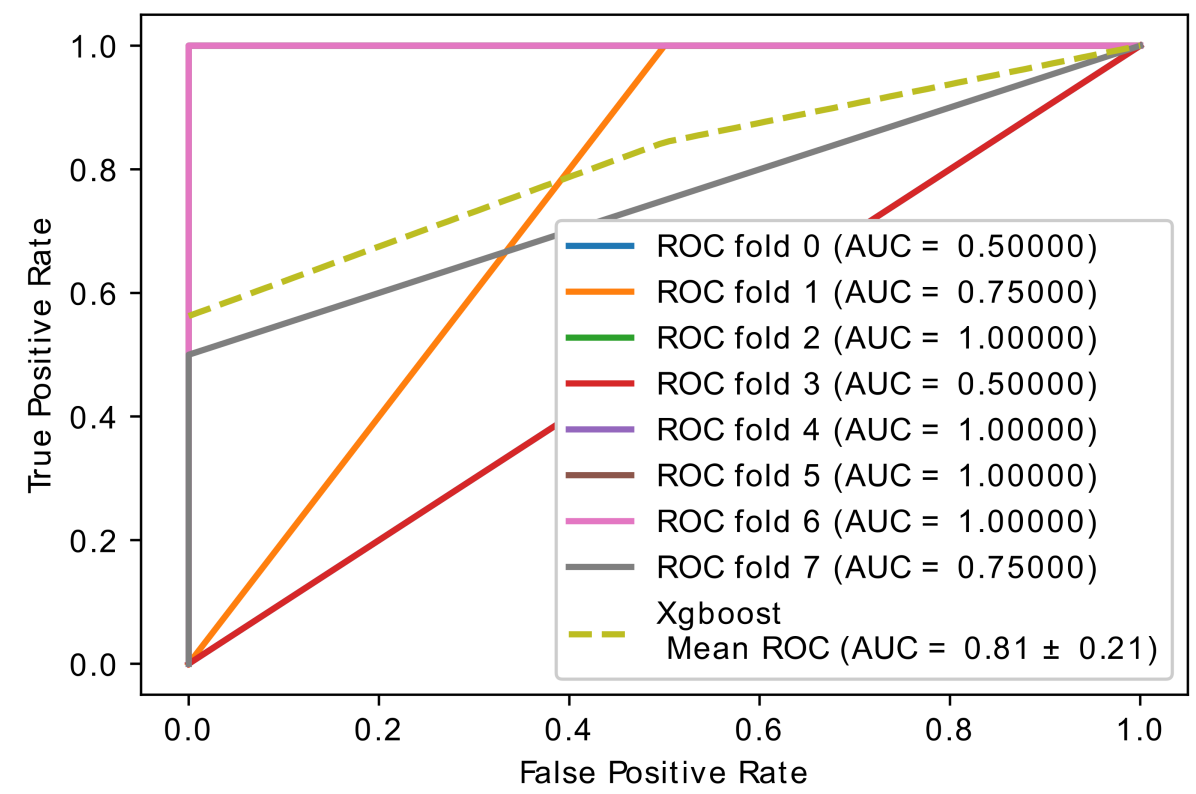

Figure 5. Accuracy curve obtained using the hybrid model with optimized XGBoost classifier.

Table 5. Training vs. testing performance of optimized Catboost with 8-fold cross-validation.

\begin{tabular}{ccc}
\hline \multirow{2}{*}{ Fold Number } & \multicolumn{2}{c}{ Optimized CatBoost Classifier } \\
\cline { 2 - 4 } & Train Accuracy & Test Accuracy \\
\hline 1 & 1.00 & 0.750 \\
2 & 1.00 & 0.750 \\
4 & 1.00 & 1.00 \\
5 & 1.00 & 1.00 \\
6 & 1.00 & 1.00 \\
7 & 1.00 & 1.00 \\
8 & 1.00 & 1.00 \\
\hline
\end{tabular}




\subsection{Experiment 2: Comparing Performance of CatBoost and Optimized CatBoost Classifier}

In this experiment, CatBoost and optimized CatBoost were compared with the original brain cancer microarray data (1070 feature, 28 samples). Table 6 and Figures 6 and 7 show the classification report of the CatBoost and optimized CatBoost classifier with the brain cancer microarray data. The threshold value was 0.84 , which is the threshold value with the highest accuracy (see Appendix A) with the final optimal genes (features) selected with our proposed hybrid model. The number of genes selected in each stage of feature selection is as follows:

- Number of non-zero genes importance (every fold).

- $(588,576,590,599,594,579,585,584)$.

- The number of genes selected by embedded SVM (with Redundant), 980 genes.

- The number of genes selected by embedded SVM (Unique), 671 genes.

- The final number of genes after we applied voting was 50 genes.

Table 6. Classification report for CatBoost and optimized CatBoost.

\begin{tabular}{|c|c|c|c|c|c|c|c|c|}
\hline \multirow{2}{*}{$\begin{array}{c}\text { Brain Cancer } \\
\text { Dataset }\end{array}$} & \multicolumn{4}{|c|}{ CatBoost } & \multicolumn{4}{|c|}{ Optimized CatBoost } \\
\hline & Precision & Recall & f1-Score & Support & Precision & Recall & f1-Score & Support \\
\hline 0.0 & 0.85 & 0.79 & 0.81 & 14 & 0.92 & 0.79 & 0.85 & 14 \\
\hline 1.0 & 0.80 & 0.86 & 0.83 & 14 & 0.81 & 0.93 & 0.87 & 14 \\
\hline accuracy & & & 0.82 & 14 & & & 0.82 & 14 \\
\hline Macro avg & 0.82 & 0.82 & 0.82 & 28 & 0.82 & 0.82 & 0.82 & 28 \\
\hline Weighted avg & 0.82 & 0.82 & 0.82 & 28 & 0.82 & 0.82 & 0.82 & 28 \\
\hline
\end{tabular}

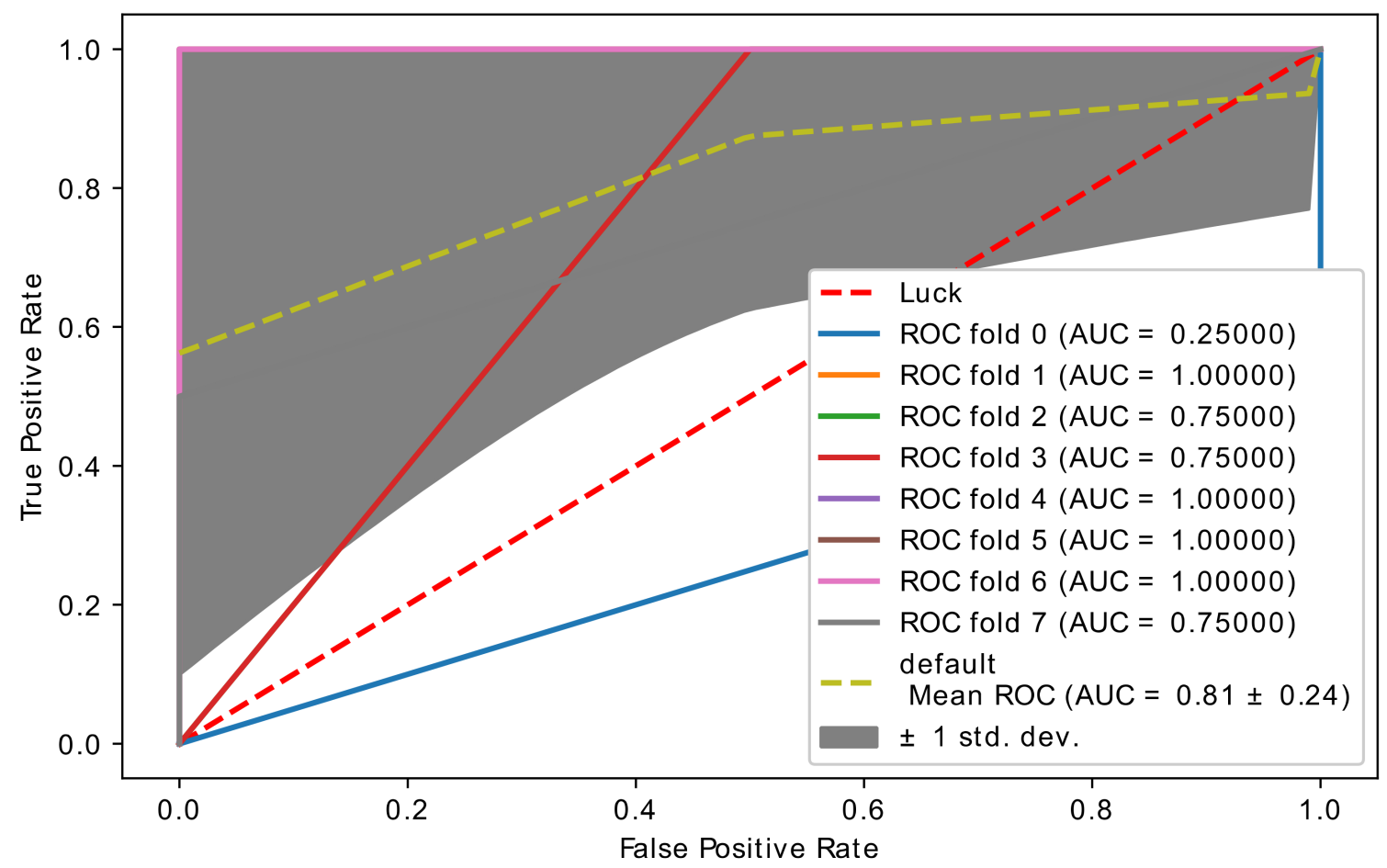

Figure 6. Accuracy curve obtained using the hybrid model with CatBoost classifier. 


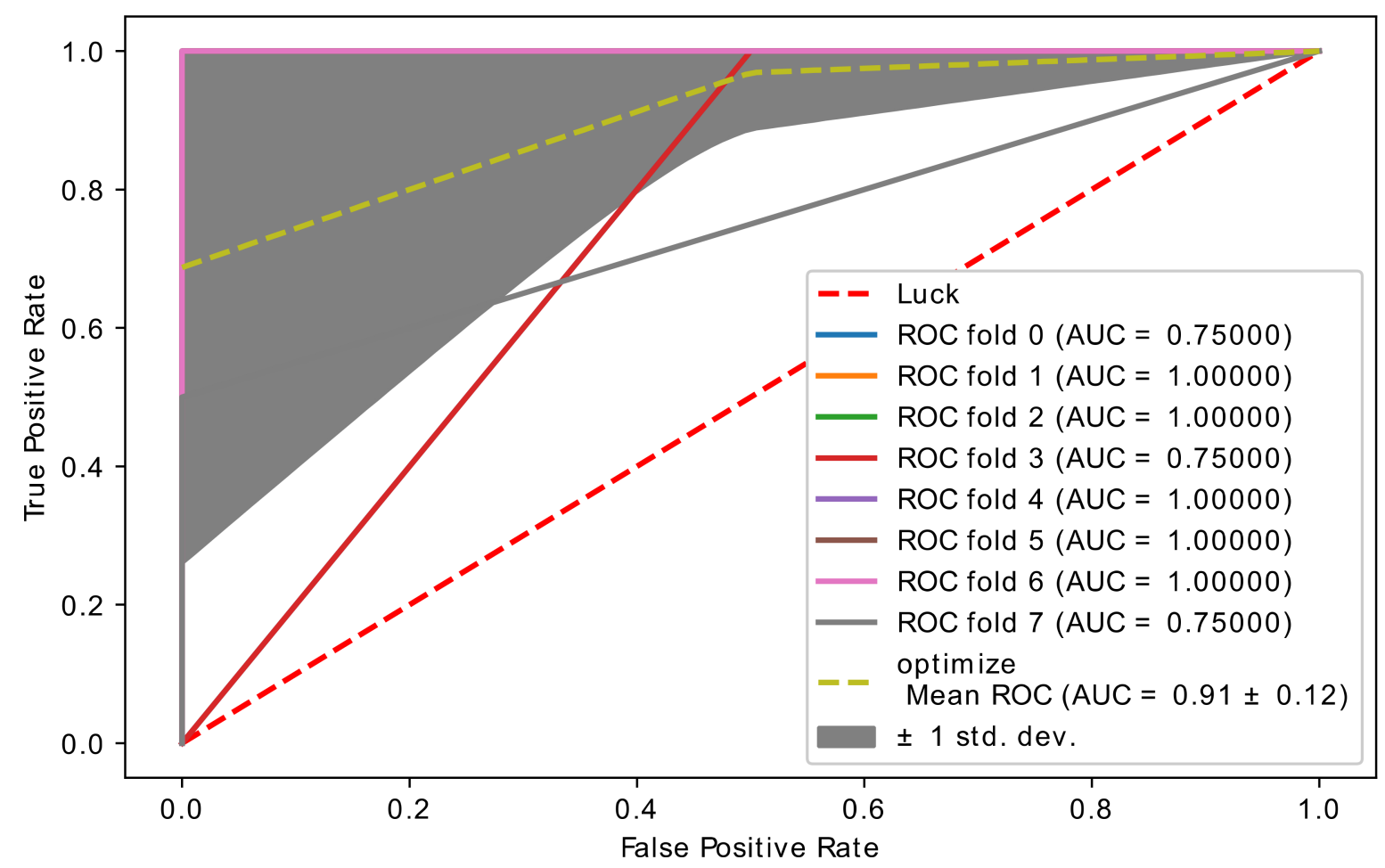

Figure 7. Accuracy curve obtained using the hybrid model with optimized CatBoost classifier.

Based on the performance metrics in Table 6, optimized CatBoost had higher performance than the CatBoost classifier without optimization. Figures 6 and 7 show the accuracy curve of CatBoost and the optimized CatBoost classifier. The optimized CatBoost classifier had an accuracy of $0.91 \pm 0.12$, which is higher than that of the CatBoost classifier without optimization, which had an accuracy of $0.81 \pm 0.24$.

\subsection{Experiment 3: Comparison of Hybrid Proposed Model Performance by Different Classification}

The classic learning algorithms random forest (RF), naive Bayes (NB), and support vector machines (SVM) were used to assess the gene classification accuracy of selected optimal genes by the proposed hybrid model. These learning algorithms were applied to the newly collected dataset, which only included the best genes, and the overall accuracy was calculated. In Figures 8-10, the learning accuracy of three classifiers is illustrated using the newly generated gene (feature) set. The proposed hybrid model increased the accuracy of the SVM, RF, and NB classifiers while the accuracy is weighted on brain data set; on the other hand, SVM and RF, with accuracies of $(0.97 \pm 0.08)$, achieve equal and higher classification accuracy than the NB $(0.91 \pm 0.12)$ classifier.

\subsection{Biological Interpretation}

A subset of genes (features) from the brain cancer data set was biologically interpreted to demonstrate the proposed model's efficacy in improving critical items such as classification accuracy and for selecting genes with important biological backgrounds. A few classes of important genes derived from microarray technologies were used to diagnose and to provide the prognostic purposes of brain cancer after using the proposed hybrid model's biological portrait.

The proposed hybrid model aims to determine crucial gene subsets with the maximum amount of accuracy needed to treat a brain cancer patient. In this segment, the selected group of probe sets could be studied by using the web tool DAVID (Database for Annotation, Integrated Discovery, and Visualization) https: / / david.ncifcrf.gov/list.jsp (accessed on 18 June 2020) [31,39]. Table 7 shows the gene name and gene ID from the Entrez probe 
set. GO Research Tools: http:/ /www.geneontology.org/GO.tools.microarray, (accessed on 18 June 2020) are generally considered to be the most inclusive and fastest-growing public repository for grouping functionally related genes. Following that, it can be shown that the proposed approach is the most effective way to pick a large group of genes for brain cancer pathway detection and prognosis.

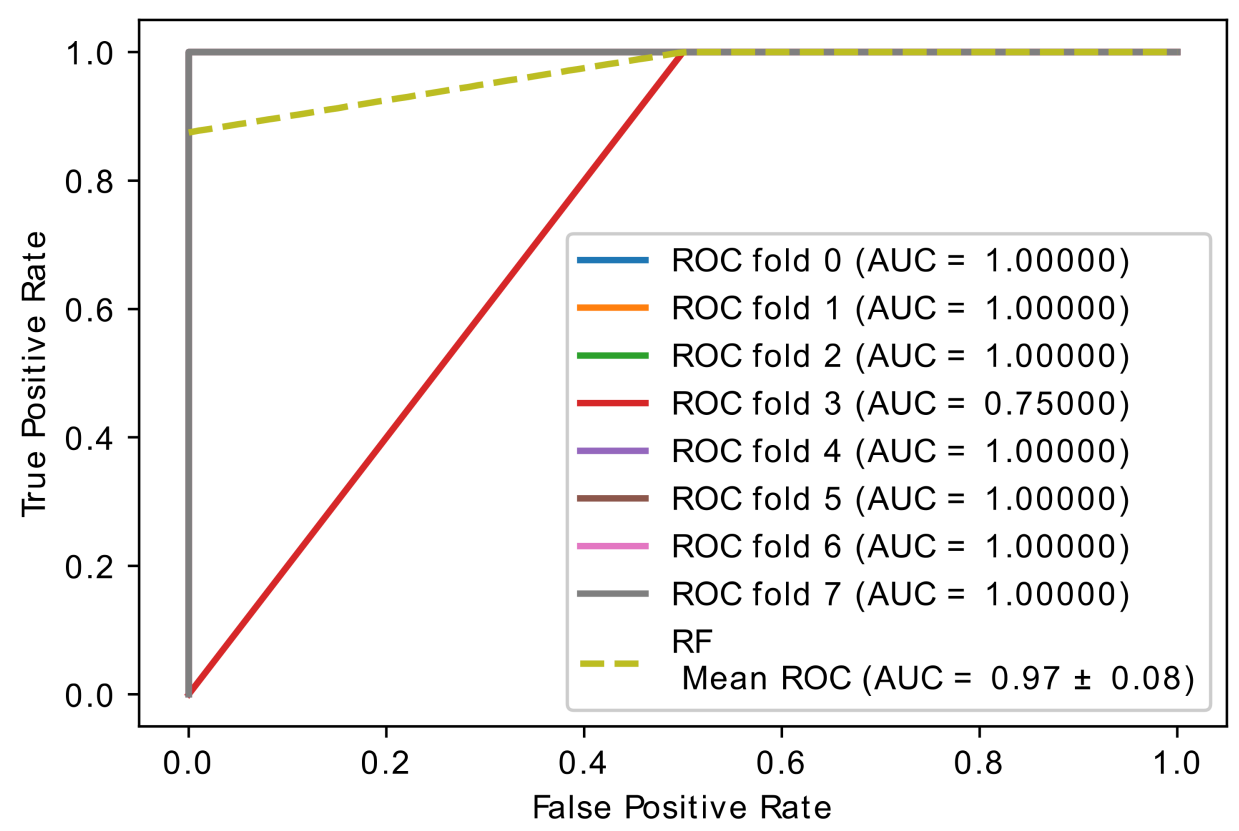

Figure 8. Accuracy curve of random forest classifier.

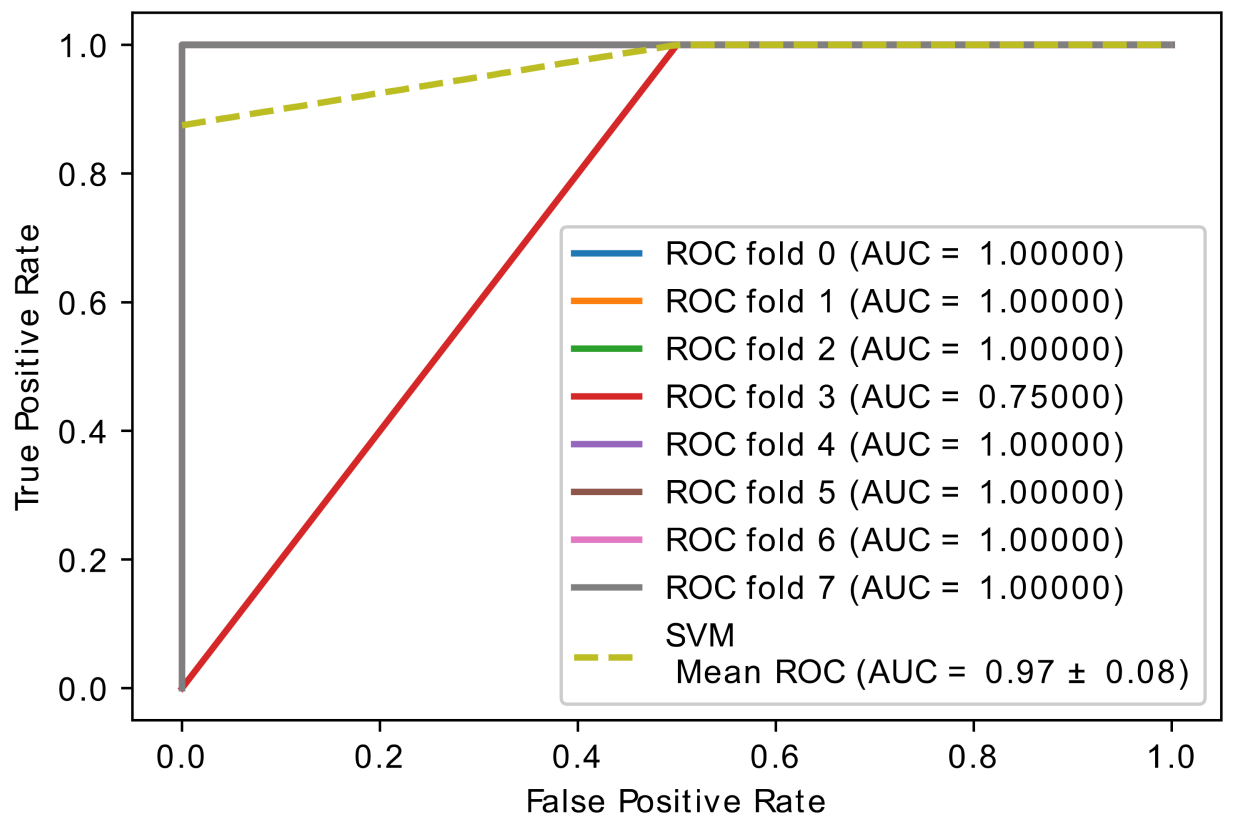

Figure 9. Accuracy curve of SVM classifier. 


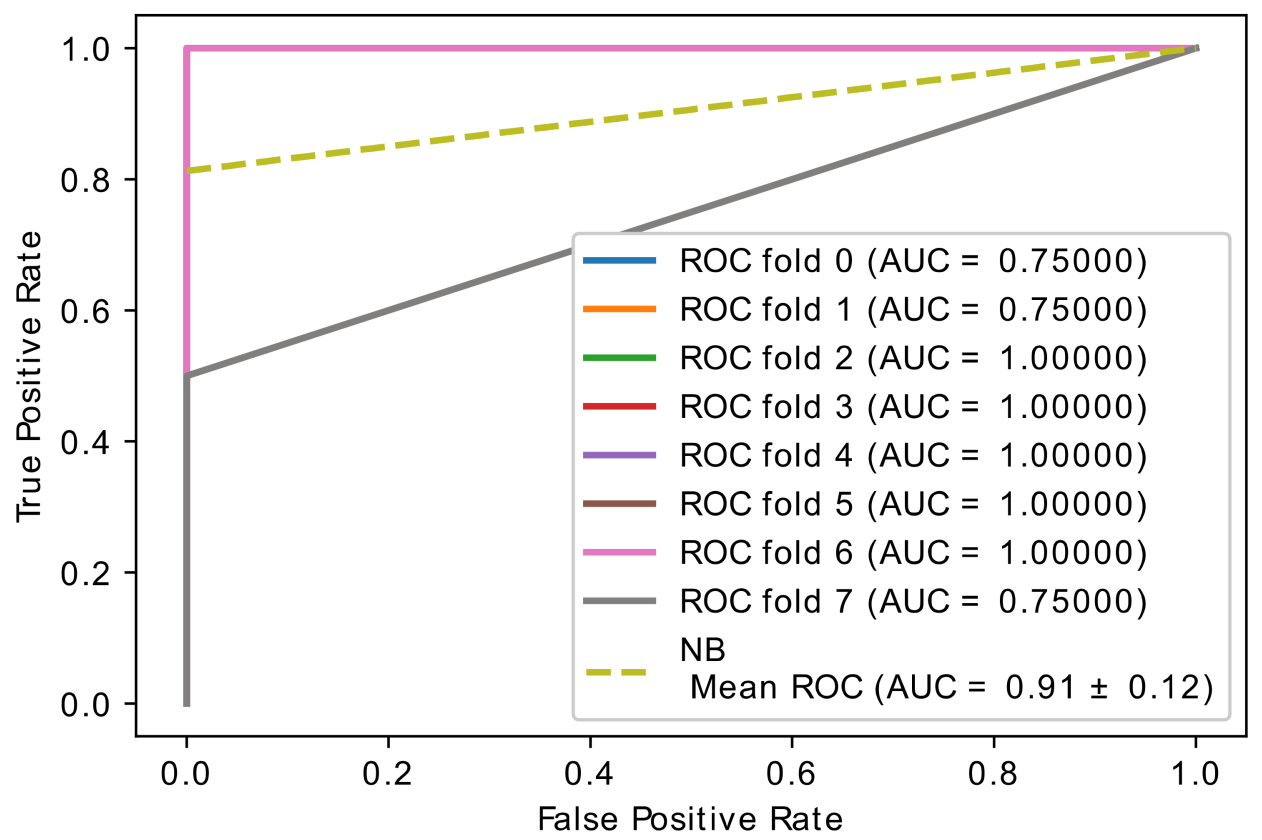

Figure 10. Accuracy curve of NB classifier.

Table 7. Gene accession number and gene description of the selected genes of brain cancer by the proposed hybrid model.

\begin{tabular}{|c|c|c|c|c|c|c|}
\hline Prob set & Gene ID & Gene Name & $\begin{array}{l}\text { Diagnostic } \\
\text { Marker }\end{array}$ & $\begin{array}{l}\text { Prognostic } \\
\text { Marker }\end{array}$ & Overexpression & $\begin{array}{l}\text { Down } \\
\text { Expression }\end{array}$ \\
\hline 1860_at & 1860 & $\begin{array}{l}\text { Tumor protein p53 binding } \\
\text { protein } 2(\mathrm{TP} 53 \mathrm{BP} 2)\end{array}$ & & Unfavorable & + & \\
\hline 286_at & 286 & $\begin{array}{l}\text { Histone cluster } 2 \text { H2A family } \\
\text { member a4(HIST2H2AA4) }\end{array}$ & Yes & & + & \\
\hline 31667_r_at & 31667_r & $\begin{array}{l}\text { Nuclear receptor subfamily } 2 \\
\text { group E member 3(NR2E3) }\end{array}$ & Yes & & + & \\
\hline 33242_at & 33242 & $\begin{array}{l}\text { TSR2, ribosome maturation } \\
\text { factor(TSR2) }\end{array}$ & Yes & & + & \\
\hline 34088_at & 34088 & Neurexophilin 4(NXPH4) & & Unfavorable & + & \\
\hline 37055_at & 37055 & ETS variant 1(ETV1) & & Unfavorable & + & \\
\hline 37701_at & 37701 & $\begin{array}{l}\text { Regulator of G-protein signaling } \\
\text { 2(RGS2) }\end{array}$ & & Unfavorable & + & \\
\hline 40388_at & 40388 & $\begin{array}{l}\text { DLG associated protein } \\
\text { 1(DLGAP1) }\end{array}$ & & Unfavorable & & \\
\hline 41098_at & 41098 & $\begin{array}{l}\text { Dishevelled associated activator of } \\
\text { morphogenesis 2(DAAM2) }\end{array}$ & & + & & \\
\hline 1972_s_at & 1972_s & $\begin{array}{l}\text { Microtubule associated protein } \\
\text { 2(MAP2) }\end{array}$ & & Unfavorable & + & \\
\hline 32647_at & 32647 & $\begin{array}{l}\text { Vesicle transport through } \\
\text { interaction with t-SNAREs } \\
\text { 1B(VTI1B) }\end{array}$ & Yes & & & + \\
\hline 36073_at & 36073 & $\begin{array}{l}\text { Necdin, MAGE family } \\
\text { member(NDN) }\end{array}$ & & Unfavorable & + & \\
\hline
\end{tabular}


Table 7. Cont.

\begin{tabular}{|c|c|c|c|c|c|c|}
\hline Prob set & Gene ID & Gene Name & $\begin{array}{l}\text { Diagnostic } \\
\text { Marker }\end{array}$ & $\begin{array}{l}\text { Prognostic } \\
\text { Marker }\end{array}$ & Overexpression & $\begin{array}{c}\text { Down } \\
\text { Expression }\end{array}$ \\
\hline 37360_at & 37360 & $\begin{array}{c}\text { Lymphocyte antigen } 6 \text { complex, } \\
\text { locus E(LY6E) }\end{array}$ & Yes & & + & \\
\hline 38420_at & 38420 & $\begin{array}{l}\text { Collagen type V alpha } 2 \\
\text { chain(COL5A2) }\end{array}$ & & Unfavorable & + & \\
\hline 39673_i_at & 39673_i & $\begin{array}{l}\text { Extracellular matrix protein } \\
\text { 2(ECM2) }\end{array}$ & & Unfavorable & & + \\
\hline 41387_r_at & 41387_r & Lysine demethylase 6B(KDM6B) & & Unfavorable & + & \\
\hline 41407_at & 41407 & MicroRNA 1236(MIR1236) & & Unfavorable & + & \\
\hline 41725_at & 41725 & $\begin{array}{l}\text { Casein kinase } 1 \text { gamma } \\
\text { 2(CSNK1G2) }\end{array}$ & & Unfavorable & + & \\
\hline 41732_at & 41732 & BolA family member 2(BOLA2) & & Favorable & + & \\
\hline 103_at & 103 & Thrombospondin 4(THBS4) & & Unfavorable & & + \\
\hline 1230_g_at & 1230_g & $\begin{array}{l}\text { Myotubularin related protein } \\
\text { 11(MTMR11) }\end{array}$ & Yes & & & + \\
\hline 1396_at & 1396 & $\begin{array}{l}\text { Insulin like growth factor binding } \\
\text { protein } 5(\text { IGFBP5) }\end{array}$ & & Unfavorable & + & \\
\hline 32988_at & 32988 & $\begin{array}{l}\text { Chloride voltage-gated channel } \\
\mathrm{Ka}(\text { CLCNKA) }\end{array}$ & & Unfavorable & + & \\
\hline 33854_at & 33854 & $\begin{array}{l}\text { ATPase } \mathrm{H}+\text { transporting V1 } \\
\text { subunit D(ATP6V1D) }\end{array}$ & & Unfavorable & + & \\
\hline 37209_g_at & 37209_g & $\begin{array}{c}\text { Phosphoserine } \\
\text { phosphatase(PSPH) }\end{array}$ & & Unfavorable & + & \\
\hline 35297_at & 35297 & $\begin{array}{l}\text { NADH:ubiquinone } \\
\text { oxidoreductase subunit } \\
\text { AB1(NDUFAB1) }\end{array}$ & & Unfavorable & + & \\
\hline 36155_at & 36155 & $\begin{array}{l}\text { SPARC/osteonectin, cwcv and } \\
\text { kazal-like domains proteoglycan } \\
\text { 2(SPOCK2) }\end{array}$ & & Favorable & + & \\
\hline 36534_at & 36534 & $\begin{array}{l}\text { DIX domain containing } \\
\text { 1(DIXDC1) }\end{array}$ & & Unfavorable & + & \\
\hline 36617_at & 36617 & $\begin{array}{l}\text { Inhibitor of DNA binding 1, HLH } \\
\text { protein(ID1) }\end{array}$ & & Unfavorable & & + \\
\hline 38440_s_at & 38440_s & $\begin{array}{c}\text { Armadillo repeat containing, } \\
\text { X-linked 6(ARMCX6) }\end{array}$ & & Unfavorable & + & \\
\hline 39315_at & 39315 & Angiopoietin 1(ANGPT1) & & Unfavorable & + & \\
\hline 39364_s_at & 39364_s & $\begin{array}{c}\text { Protein phosphatase } 1 \text { regulatory } \\
\text { subunit 3C(PPP1R3C) }\end{array}$ & & Unfavorable & & \\
\hline 39512_s_at & 39512_s & $\begin{array}{c}\text { Inositol } \\
\text { polyphosphate-4-phosphatase } \\
\text { type I A(INPP4A) }\end{array}$ & & + & & \\
\hline 39850_at & 39850 & Ankyrin 2(ANK2) & & Unfavorable & + & \\
\hline 755_at & 755 & $\begin{array}{l}\text { Inositol 1,4,5-trisphosphate } \\
\text { receptor type 1(ITPR1) }\end{array}$ & & & & \\
\hline
\end{tabular}


Table 7. Cont.

\begin{tabular}{|c|c|c|c|c|c|c|}
\hline Prob set & Gene ID & Gene Name & $\begin{array}{l}\text { Diagnostic } \\
\text { Marker }\end{array}$ & $\begin{array}{c}\text { Prognostic } \\
\text { Marker }\end{array}$ & Overexpression & $\begin{array}{c}\text { Down } \\
\text { Expression }\end{array}$ \\
\hline 31386_at & 31386 & $\begin{array}{c}\text { Immunoglobulin kappa variable } \\
\text { 1/OR2-118 (IGKV1OR2-118) } \\
\text { (pseudogene) }\end{array}$ & & Unfavorable & + & \\
\hline 33580_r_at & 33580_r & Galanin receptor 3(GALR3) & & & + & \\
\hline 34193_at & 34193 & $\begin{array}{c}\text { Cell adhesion molecule L1 } \\
\text { like(CHL1) }\end{array}$ & & Unfavorable & + & \\
\hline 35349_at & 35349 & $\begin{array}{c}\text { COP9 signalosome subunit } \\
\text { 3(COPS3) }\end{array}$ & & Unfavorable & & + \\
\hline 35719_at & 35719 & $\begin{array}{l}\text { PH domain and leucine rich } \\
\text { repeat protein phosphatase } \\
1(\text { PHLPP1) }\end{array}$ & & Unfavorable & + & \\
\hline 38967_at & 38967 & $\begin{array}{l}\text { Chromosome } 14 \text { open reading } \\
\text { frame } 2 \text { (C14orf } 2)\end{array}$ & & Unfavorable & + & \\
\hline 39329_at & 39329 & Actinin alpha $1(\mathrm{ACTN} 1)$ & yes & Unfavorable & + & \\
\hline 41530_at & 41530 & $\begin{array}{l}\text { Acetyl-CoA acyltransferase } \\
\text { 2(ACAA2) }\end{array}$ & & Favorable & + & \\
\hline 38397_at & 38397 & $\begin{array}{l}\text { DNA polymerase delta } 4, \\
\text { accessory subunit(POLD4) }\end{array}$ & & Unfavorable & & \\
\hline 39008_at & 39008 & Ceruloplasmin(CP) & & & & \\
\hline 40767_at & 40767 & $\begin{array}{l}\text { Tissue factor pathway } \\
\text { inhibitor(TFPI) }\end{array}$ & & Unfavorable & + & \\
\hline 41214_at & 41214 & $\begin{array}{c}\text { Ribosomal protein S4, Y-linked } \\
\text { 1(RPS4Y1) }\end{array}$ & & Unfavorable & + & \\
\hline 31342_at & 31342 & $\begin{array}{c}\text { Polypeptide N- } \\
\text { acetylgalactosaminyltransferase } \\
2(\text { GALNT2) }\end{array}$ & & Unfavorable & + & \\
\hline 32109_at & 32109 & $\begin{array}{l}\text { FXYD domain-containing ion } \\
\text { transport regulator } 1(\mathrm{FXYD} 1)\end{array}$ & yes & Unfavorable & + & \\
\hline 32458_f_at & 32458_f & $\begin{array}{l}\text { Proline rich protein BstNI } \\
\text { subfamily } 4 \text { (PRB4) }\end{array}$ & & Unfavorable & + & \\
\hline
\end{tabular}

In Figure 11, heat maps representing the frequency of selected features over the crossvalidation analysis are used to evaluate the consistency of the selected features over time and to identify genes that are differentially expressed between the two disease classes (cancer class and healthy class).

Figure 12 shows the correlation among the selected feature using our proposed model with the Catboost classifier. The correlation coefficient has values between -1 to 1 . A value closer to 0 implies a weaker correlation (exact 0 implying no correlation). A value closer to 1 implies a stronger positive correlation, and a value closer to -1 implies a stronger negative correlation. We compared the correlation between features and removed one of two features that correlate to $>=0.5$, that correlate to $=0.5$ in the first threshold, and to $0.5+0.01$ in the second fold of the threshold. 


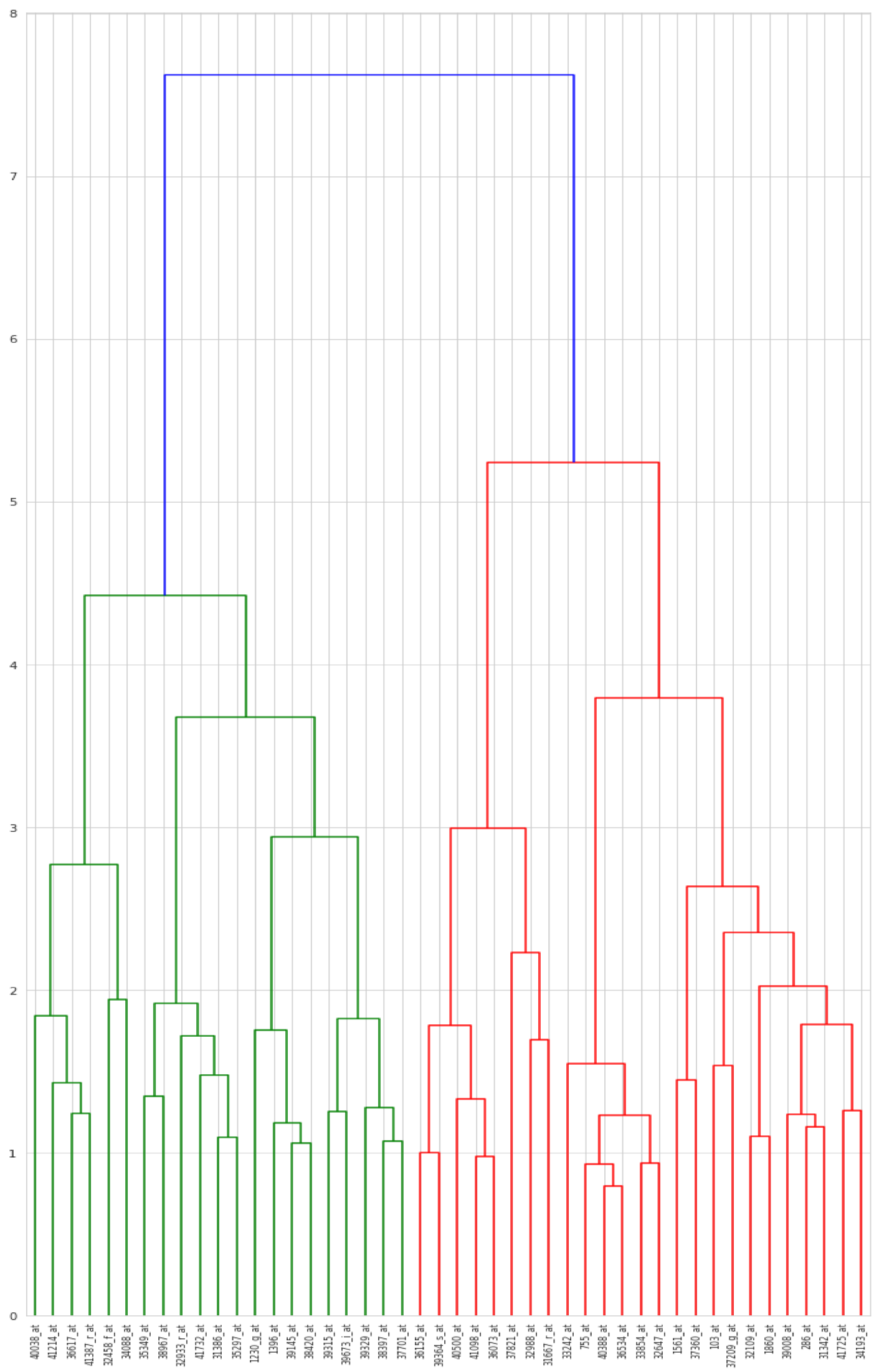

(a)

Figure 11. Cont. 


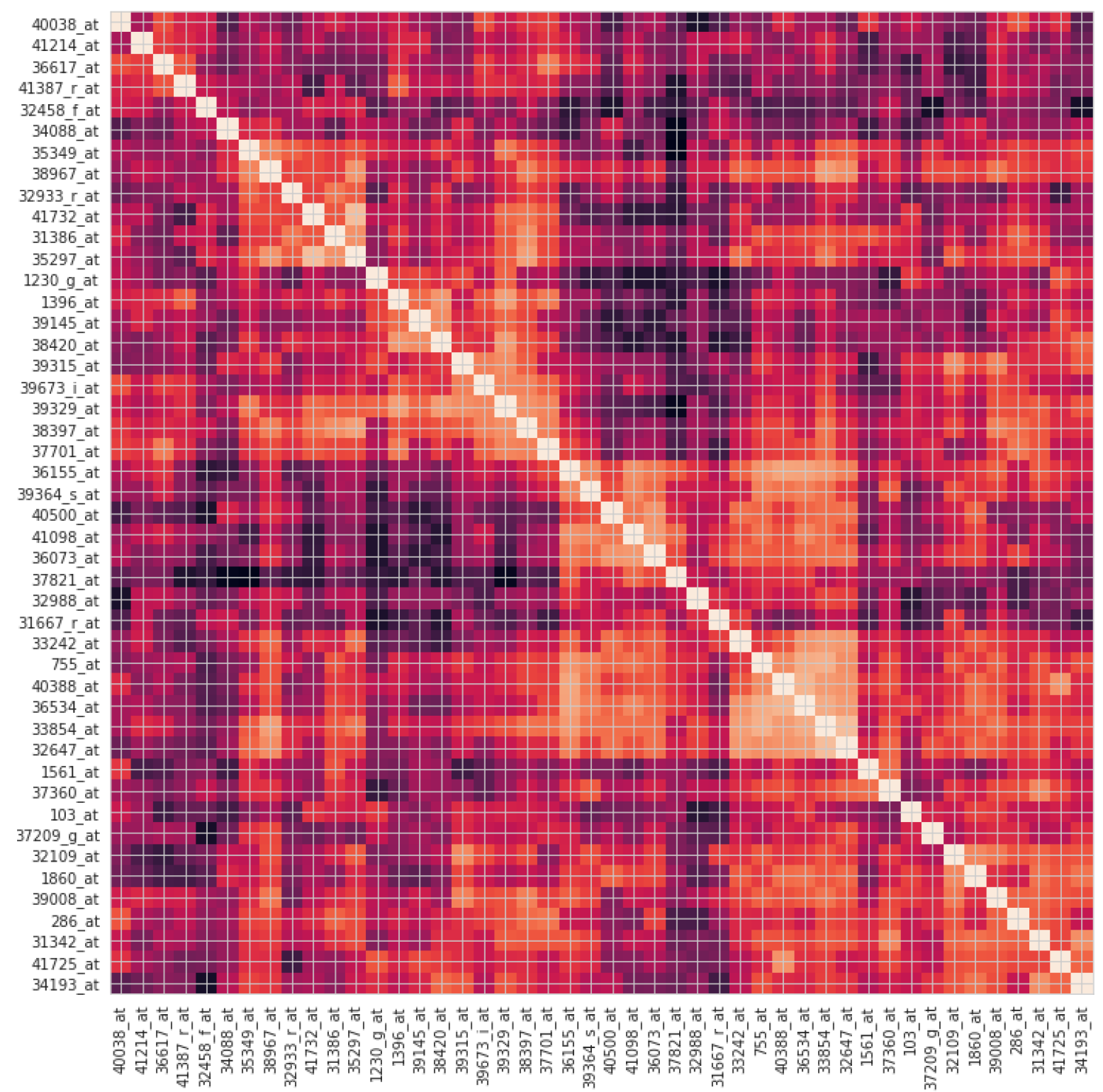

(b)

Figure 11. (a) Hierarchical clustering dendrogram maps of the genes selected in the proposed hybrid model. (b) Heat maps of the genes selected in the proposed hybrid model. 


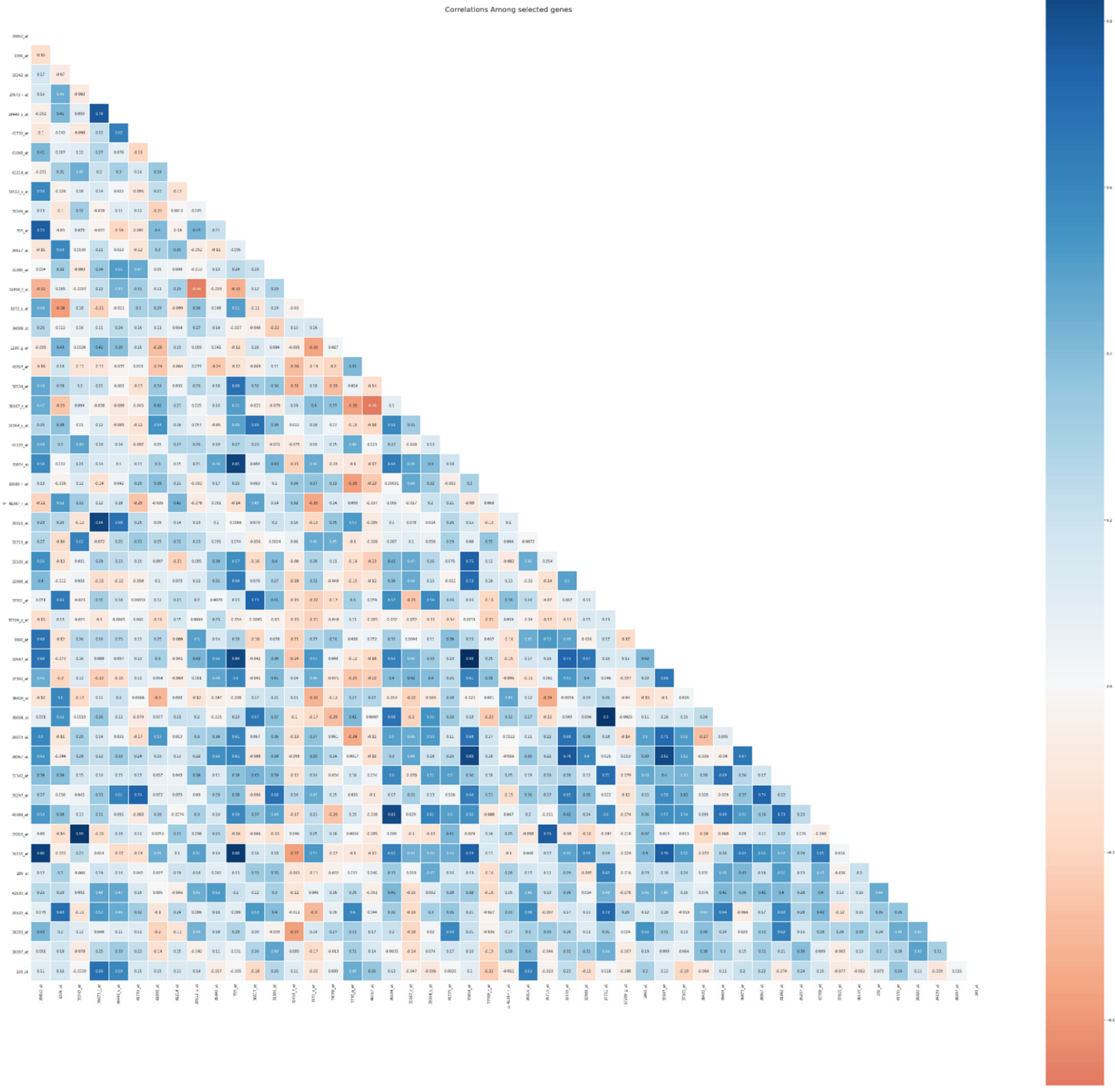

Figure 12. The correlation among the selected genes with the proposed hybrid mode.

\section{Conclusions}

Brain disorders are becoming a major issue, particularly malignant brain tumors, which significantly impact people's lives. The brain cancer microarray data have proven to be a complicated classification task due to the small number of samples that have a large number of gene expression levels as features. As part of brain cancer microarray data analysis, the present study proposed an effective and powerful technique for the selection of significant and relevant genes with biomedical relevance. Three distinct techniques were used for classification and prediction (feature selection, optimization, and classification). We used the same dataset and three different algorithms to evaluate the performance of the proposed model (NB, RF, and SVM). The experimental results demonstrate that the proposed hybrid model significantly improves critical items such as classification accuracy and that the selected genes have an important biological background. 
Furthermore, selecting optimal genes (features) with biological significance can assist biological researchers in brain cancer treatment. The major contributions of this paper are: (a) The application of Catboost and XGboost on high-dimensional microarray data to create a cancer microarray dataset; (b) the use of the hyperboot optimizer to optimize the hyperparameters of the two classifiers, and the outperformance of the Catboost on XGboost in terms of AUC, Sen, Spec, and accuracy; (c) the selection of genes that are non-redundant and relevant to the biological context using ensemble mRMR, which leads to more detailed biological interpretations. Later, the output of the gene subset was combined with the Catboost-selected features. Then, a voting process was applied to obtain unique, informative genes (features) with high relevance and minimum redundancy; (d) the selected genes in our proposed model were biologically interpreted, and the results agree with the findings of relevant biomedical studies. Developing robustness should be a priority for future work.

Author Contributions: Conceptualization: A.M.A., M.Q.; Data curation, H.F., A.K.K.; Formal analysis, A.M.A., H.F.; Investigation, A.M.A., H.F., A.K.K.; Methodology, A.M.A., M.Q., S.A. and M.E.; Software, A.M.A., N.K.H.; Supervision, M.E.; Validation, A.M.A., M.Q. and M.E.; Visualization, H.F., N.K.H.; Writing-original draft, A.M.A., H.F., M.A.; Writing-review \& editing, A.M.A., M.A. and M.E. All authors have read and agreed to the published version of the manuscript.

Funding: This research received no external funding.

Institutional Review Board Statement: Not applicable.

Informed Consent Statement: Not applicable.

Data Availability Statement: Data available upon request.

Conflicts of Interest: The authors declare no conflict of interest. 


\section{Appendix A}

\begin{tabular}{|c|c|c|c|c|c|c|c|c|c|c|c|c|c|c|c|c|}
\hline \multirow{2}{*}{$\begin{array}{l}\text { Threshold } \\
\text { (28: 1068) }\end{array}$} & \multicolumn{4}{|c|}{ SVM } & \multicolumn{4}{|c|}{ Random Forest } & \multicolumn{4}{|c|}{ Naive Bayes } & \multicolumn{4}{|c|}{ CatBoost } \\
\hline & Accuracy & Spec & SEN & AUC & Accuracy & Spec & SEN & AUC & Accuracy & Spec & SEN & AUC & Accuracy & Spec & SEN & AUC \\
\hline 0.5 & $\begin{array}{c}0.91 \pm \\
0.17\end{array}$ & $\begin{array}{c}1.00 \pm \\
0.00\end{array}$ & $\begin{array}{c}0.81 \pm \\
0.35\end{array}$ & $\begin{array}{c}0.91 \pm \\
0.17\end{array}$ & $\begin{array}{c}0.97 \pm \\
0.08\end{array}$ & $\begin{array}{c}1.00 \pm \\
0.00\end{array}$ & $\begin{array}{c}0.94 \pm \\
0.17\end{array}$ & $\begin{array}{c}0.97 \pm \\
0.08\end{array}$ & $\begin{array}{c}1.00 \pm \\
0.00\end{array}$ & $\begin{array}{c}1.00 \pm \\
0.00\end{array}$ & $\begin{array}{c}1.00 \pm \\
0.00\end{array}$ & $\begin{array}{c}1.00 \pm \\
0.00\end{array}$ & $\begin{array}{c}0.91 \pm \\
0.12\end{array}$ & $\begin{array}{c}0.94 \pm \\
0.17\end{array}$ & $\begin{array}{c}0.88 \pm \\
0.22\end{array}$ & $\begin{array}{c}0.91 \pm \\
0.12\end{array}$ \\
\hline 0.51 & $\begin{array}{c}0.91 \pm \\
0.17\end{array}$ & $\begin{array}{c}1.00 \pm \\
0.00\end{array}$ & $\begin{array}{c}0.81 \pm \\
0.35\end{array}$ & $\begin{array}{c}0.91 \pm \\
0.17\end{array}$ & $\begin{array}{c}0.97 \pm \\
0.08\end{array}$ & $\begin{array}{c}0.94 \pm \\
0.17\end{array}$ & $\begin{array}{c}1.00 \pm \\
0.00\end{array}$ & $\begin{array}{c}0.97 \pm \\
0.08\end{array}$ & $\begin{array}{c}1.00 \pm \\
0.00\end{array}$ & $\begin{array}{c}1.00 \pm \\
0.00\end{array}$ & $\begin{array}{c}1.00 \pm \\
0.00\end{array}$ & $\begin{array}{c}1.00 \pm \\
0.00\end{array}$ & $\begin{array}{c}0.91 \pm \\
0.12\end{array}$ & $\begin{array}{c}0.94 \pm \\
0.17\end{array}$ & $\begin{array}{c}0.88 \pm \\
0.22\end{array}$ & $\begin{array}{c}0.91 \pm \\
0.12\end{array}$ \\
\hline 0.52 & $\begin{array}{c}0.91 \pm \\
0.17\end{array}$ & $\begin{array}{c}1.00 \pm \\
0.00\end{array}$ & $\begin{array}{c}0.81 \pm \\
0.35\end{array}$ & $\begin{array}{c}0.91 \pm \\
0.17\end{array}$ & $\begin{array}{c}0.91 \pm \\
0.17 \\
\end{array}$ & $\begin{array}{c}0.88 \pm \\
0.33 \\
\end{array}$ & $\begin{array}{c}0.94 \pm \\
0.17\end{array}$ & $\begin{array}{c}0.91 \pm \\
0.17 \\
\end{array}$ & $\begin{array}{c}1.00 \pm \\
0.00\end{array}$ & $\begin{array}{c}1.00 \pm \\
0.00\end{array}$ & $\begin{array}{c}1.00 \pm \\
0.00\end{array}$ & $\begin{array}{c}1.00 \pm \\
0.00\end{array}$ & $\begin{array}{c}0.91 \pm \\
0.12 \\
\end{array}$ & $\begin{array}{c}0.94 \pm \\
0.17\end{array}$ & $\begin{array}{c}0.88 \pm \\
0.22\end{array}$ & $\begin{array}{c}0.91 \pm \\
0.12 \\
\end{array}$ \\
\hline 0.53 & $\begin{array}{c}0.91 \pm \\
0.17 \\
\end{array}$ & $\begin{array}{c}1.00 \pm \\
0.00\end{array}$ & $\begin{array}{c}0.81 \pm \\
0.35\end{array}$ & $\begin{array}{c}0.91 \pm \\
0.17\end{array}$ & $\begin{array}{c}0.94 \pm \\
0.11 \\
\end{array}$ & $\begin{array}{c}1.00 \pm \\
0.00 \\
\end{array}$ & $\begin{array}{c}0.88 \pm \\
0.22\end{array}$ & $\begin{array}{c}0.94 \pm \\
0.11 \\
\end{array}$ & $\begin{array}{c}1.00 \pm \\
0.00\end{array}$ & $\begin{array}{c}1.00 \pm \\
0.00\end{array}$ & $\begin{array}{c}1.00 \pm \\
0.00\end{array}$ & $\begin{array}{c}1.00 \pm \\
0.00\end{array}$ & $\begin{array}{c}0.91 \pm \\
0.12 \\
\end{array}$ & $\begin{array}{c}0.94 \pm \\
0.17\end{array}$ & $\begin{array}{c}0.88 \pm \\
0.22\end{array}$ & $\begin{array}{c}0.91 \pm \\
0.12 \\
\end{array}$ \\
\hline 0.54 & $\begin{array}{c}0.91 \pm \\
0.17\end{array}$ & $\begin{array}{c}1.00 \pm \\
0.00\end{array}$ & $\begin{array}{c}0.81 \pm \\
0.35 \\
\end{array}$ & $\begin{array}{c}0.91 \pm \\
0.17 \\
\end{array}$ & $\begin{array}{c}0.97 \pm \\
0.08\end{array}$ & $\begin{array}{c}1.00 \pm \\
0.00\end{array}$ & $\begin{array}{c}0.94 \pm \\
0.17 \\
\end{array}$ & $\begin{array}{c}0.97 \pm \\
0.08\end{array}$ & $\begin{array}{c}1.00 \pm \\
0.00\end{array}$ & $\begin{array}{c}1.00 \pm \\
0.00\end{array}$ & $\begin{array}{c}1.00 \pm \\
0.00\end{array}$ & $\begin{array}{c}1.00 \pm \\
0.00\end{array}$ & $\begin{array}{c}0.91 \pm \\
0.12\end{array}$ & $\begin{array}{c}0.94 \pm \\
0.17 \\
\end{array}$ & $\begin{array}{c}0.88 \pm \\
0.22 \\
\end{array}$ & $\begin{array}{c}0.91 \pm \\
0.12 \\
\end{array}$ \\
\hline 0.55 & $\begin{array}{c}0.91 \pm \\
0.17\end{array}$ & $\begin{array}{c}1.00 \pm \\
0.00\end{array}$ & $\begin{array}{c}0.81 \pm \\
0.35\end{array}$ & $\begin{array}{c}0.91 \pm \\
0.17\end{array}$ & $\begin{array}{c}0.93 \pm \\
0.13 \\
\end{array}$ & $\begin{array}{c}1.00 \pm \\
0.00 \\
\end{array}$ & $\begin{array}{c}0.88 \pm \\
0.22\end{array}$ & $\begin{array}{c}0.94 \pm \\
0.11 \\
\end{array}$ & $\begin{array}{c}1.00 \pm \\
0.00\end{array}$ & $\begin{array}{c}1.00 \pm \\
0.00\end{array}$ & $\begin{array}{c}1.00 \pm \\
0.00\end{array}$ & $\begin{array}{c}1.00 \pm \\
0.00\end{array}$ & $\begin{array}{c}0.91 \pm \\
0.12 \\
\end{array}$ & $\begin{array}{c}0.94 \pm \\
0.17\end{array}$ & $\begin{array}{c}0.88 \pm \\
0.22\end{array}$ & $\begin{array}{c}0.91 \pm \\
0.12 \\
\end{array}$ \\
\hline 0.56 & $\begin{array}{c}0.91 \pm \\
0.17\end{array}$ & $\begin{array}{c}1.00 \pm \\
0.00\end{array}$ & $\begin{array}{c}0.81 \pm \\
0.35\end{array}$ & $\begin{array}{c}0.91 \pm \\
0.17\end{array}$ & $\begin{array}{c}0.97 \pm \\
0.08\end{array}$ & $\begin{array}{c}1.00 \pm \\
0.00 \\
\end{array}$ & $\begin{array}{c}0.94 \pm \\
0.17\end{array}$ & $\begin{array}{c}0.97 \pm \\
0.08\end{array}$ & $\begin{array}{c}1.00 \pm \\
0.00\end{array}$ & $\begin{array}{c}1.00 \pm \\
0.00\end{array}$ & $\begin{array}{c}1.00 \pm \\
0.00\end{array}$ & $\begin{array}{c}1.00 \pm \\
0.00\end{array}$ & $\begin{array}{c}0.91 \pm \\
0.12 \\
\end{array}$ & $\begin{array}{c}0.94 \pm \\
0.17\end{array}$ & $\begin{array}{c}0.88 \pm \\
0.22\end{array}$ & $\begin{array}{c}0.91 \pm \\
0.12 \\
\end{array}$ \\
\hline 0.57 & $\begin{array}{c}0.91 \pm \\
0.17\end{array}$ & $\begin{array}{c}1.00 \pm \\
0.00\end{array}$ & $\begin{array}{c}0.81 \pm \\
0.35\end{array}$ & $\begin{array}{c}0.91 \pm \\
0.17\end{array}$ & $\begin{array}{c}0.94 \pm \\
0.11\end{array}$ & $\begin{array}{c}0.94 \pm \\
0.17\end{array}$ & $\begin{array}{c}0.94 \pm \\
0.17\end{array}$ & $\begin{array}{c}0.94 \pm \\
0.11\end{array}$ & $\begin{array}{c}1.00 \pm \\
0.00\end{array}$ & $\begin{array}{c}1.00 \pm \\
0.00\end{array}$ & $\begin{array}{c}1.00 \pm \\
0.00\end{array}$ & $\begin{array}{c}1.00 \pm \\
0.00\end{array}$ & $\begin{array}{c}0.91 \pm \\
0.12\end{array}$ & $\begin{array}{c}0.94 \pm \\
0.17\end{array}$ & $\begin{array}{c}0.88 \pm \\
0.22\end{array}$ & $\begin{array}{c}0.91 \pm \\
0.12\end{array}$ \\
\hline 0.58 & $\begin{array}{c}0.93 \pm \\
0.13\end{array}$ & $\begin{array}{c}1.00 \pm \\
0.00\end{array}$ & $\begin{array}{c}0.88 \pm \\
0.22\end{array}$ & $\begin{array}{c}0.94 \pm \\
0.11\end{array}$ & $\begin{array}{c}0.88 \pm \\
0.12\end{array}$ & $\begin{array}{c}0.94 \pm \\
0.17\end{array}$ & $\begin{array}{c}0.81 \pm \\
0.24\end{array}$ & $\begin{array}{c}0.88 \pm \\
0.12\end{array}$ & $\begin{array}{c}0.97 \pm \\
0.08\end{array}$ & $\begin{array}{c}0.94 \pm \\
0.17\end{array}$ & $\begin{array}{c}1.00 \pm \\
0.00\end{array}$ & $\begin{array}{c}0.97 \pm \\
0.08\end{array}$ & $\begin{array}{c}0.91 \pm \\
0.12\end{array}$ & $\begin{array}{c}0.94 \pm \\
0.17\end{array}$ & $\begin{array}{c}0.88 \pm \\
0.22\end{array}$ & $\begin{array}{c}0.91 \pm \\
0.12\end{array}$ \\
\hline 0.59 & $\begin{array}{c}0.97 \pm \\
0.08\end{array}$ & $\begin{array}{c}1.00 \pm \\
0.00\end{array}$ & $\begin{array}{c}0.94 \pm \\
0.17\end{array}$ & $\begin{array}{c}0.97 \pm \\
0.08\end{array}$ & $\begin{array}{c}0.91 \pm \\
0.12\end{array}$ & $\begin{array}{c}0.94 \pm \\
0.17\end{array}$ & $\begin{array}{c}0.88 \pm \\
0.22\end{array}$ & $\begin{array}{c}0.91 \pm \\
0.12\end{array}$ & $\begin{array}{c}1.00 \pm \\
0.00\end{array}$ & $\begin{array}{c}1.00 \pm \\
0.00\end{array}$ & $\begin{array}{c}1.00 \pm \\
0.00\end{array}$ & $\begin{array}{c}1.00 \pm \\
0.00\end{array}$ & $\begin{array}{c}0.91 \pm \\
0.12\end{array}$ & $\begin{array}{c}0.94 \pm \\
0.17\end{array}$ & $\begin{array}{c}0.88 \pm \\
0.22\end{array}$ & $\begin{array}{c}0.91 \pm \\
0.12\end{array}$ \\
\hline 0.61 & $\begin{array}{c}0.97 \pm \\
0.08\end{array}$ & $\begin{array}{c}1.00 \pm \\
0.00\end{array}$ & $\begin{array}{c}0.94 \pm \\
0.17\end{array}$ & $\begin{array}{c}0.97 \pm \\
0.08\end{array}$ & $\begin{array}{c}0.86 \pm \\
0.19\end{array}$ & $\begin{array}{c}0.88 \pm \\
0.22\end{array}$ & $\begin{array}{c}0.88 \pm \\
0.22\end{array}$ & $\begin{array}{c}0.88 \pm \\
0.18\end{array}$ & $\begin{array}{c}0.97 \pm \\
0.08\end{array}$ & $\begin{array}{c}0.94 \pm \\
0.17\end{array}$ & $\begin{array}{c}1.00 \pm \\
0.00\end{array}$ & $\begin{array}{c}0.97 \pm \\
0.08\end{array}$ & $\begin{array}{c}0.90 \pm \\
0.14\end{array}$ & $\begin{array}{c}1.00 \pm \\
0.00\end{array}$ & $\begin{array}{c}0.81 \pm \\
0.24\end{array}$ & $\begin{array}{c}0.91 \pm \\
0.12\end{array}$ \\
\hline 0.62 & $\begin{array}{c}0.97 \pm \\
0.08\end{array}$ & $\begin{array}{c}1.00 \pm \\
0.00\end{array}$ & $\begin{array}{c}0.94 \pm \\
0.17\end{array}$ & $\begin{array}{c}0.97 \pm \\
0.08\end{array}$ & $\begin{array}{c}0.90 \pm \\
0.14\end{array}$ & $\begin{array}{c}0.94 \pm \\
0.17\end{array}$ & $\begin{array}{c}0.88 \pm \\
0.22\end{array}$ & $\begin{array}{c}0.91 \pm \\
0.12\end{array}$ & $\begin{array}{c}0.97 \pm \\
0.08\end{array}$ & $\begin{array}{c}0.94 \pm \\
0.17\end{array}$ & $\begin{array}{c}1.00 \pm \\
0.00\end{array}$ & $\begin{array}{c}0.97 \pm \\
0.08\end{array}$ & $\begin{array}{c}0.90 \pm \\
0.14\end{array}$ & $\begin{array}{c}1.00 \pm \\
0.00\end{array}$ & $\begin{array}{c}0.81 \pm \\
0.24\end{array}$ & $\begin{array}{c}0.91 \pm \\
0.12\end{array}$ \\
\hline 0.63 & $\begin{array}{c}0.97 \pm \\
0.08 \\
\end{array}$ & $\begin{array}{c}1.00 \pm \\
0.00 \\
\end{array}$ & $\begin{array}{c}0.94 \pm \\
0.17 \\
\end{array}$ & $\begin{array}{c}0.97 \pm \\
0.08 \\
\end{array}$ & $\begin{array}{c}0.83 \pm \\
0.18 \\
\end{array}$ & $\begin{array}{c}0.88 \pm \\
0.22 \\
\end{array}$ & $\begin{array}{c}0.81 \pm \\
0.24 \\
\end{array}$ & $\begin{array}{c}0.84 \pm \\
0.17 \\
\end{array}$ & $\begin{array}{c}0.97 \pm \\
0.08 \\
\end{array}$ & $\begin{array}{c}0.94 \pm \\
0.17 \\
\end{array}$ & $\begin{array}{c}1.00 \pm \\
0.00 \\
\end{array}$ & $\begin{array}{c}0.97 \pm \\
0.08 \\
\end{array}$ & $\begin{array}{c}0.94 \pm \\
0.11 \\
\end{array}$ & $\begin{array}{c}1.00 \pm \\
0.00\end{array}$ & $\begin{array}{c}0.88 \pm \\
0.22 \\
\end{array}$ & $\begin{array}{c}0.94 \pm \\
0.11 \\
\end{array}$ \\
\hline 0.64 & $\begin{array}{c}0.97 \pm \\
0.08\end{array}$ & $\begin{array}{c}1.00 \pm \\
0.00\end{array}$ & $\begin{array}{c}0.94 \pm \\
0.17\end{array}$ & $\begin{array}{c}0.97 \pm \\
0.08\end{array}$ & $\begin{array}{c}0.97 \pm \\
0.08\end{array}$ & $\begin{array}{c}1.00 \pm \\
0.00\end{array}$ & $\begin{array}{c}0.94 \pm \\
0.17\end{array}$ & $\begin{array}{c}0.97 \pm \\
0.08\end{array}$ & $\begin{array}{c}0.97 \pm \\
0.08\end{array}$ & $\begin{array}{c}1.00 \pm \\
0.00\end{array}$ & $\begin{array}{c}0.94 \pm \\
0.17\end{array}$ & $\begin{array}{c}0.97 \pm \\
0.08\end{array}$ & $\begin{array}{c}0.94 \pm \\
0.11\end{array}$ & $\begin{array}{c}1.00 \pm \\
0.00\end{array}$ & $\begin{array}{c}0.88 \pm \\
0.22\end{array}$ & $\begin{array}{c}0.94 \pm \\
0.11\end{array}$ \\
\hline 0.65 & $0.94 \pm 0.11$ & $\begin{array}{c}1.00 \pm \\
0.00\end{array}$ & $\begin{array}{c}0.88 \pm \\
0.22\end{array}$ & $\begin{array}{c}0.94 \pm \\
0.11\end{array}$ & $\begin{array}{c}0.97 \pm \\
0.08\end{array}$ & $\begin{array}{c}1.00 \pm \\
0.00\end{array}$ & $\begin{array}{c}0.94 \pm \\
0.17\end{array}$ & $\begin{array}{c}0.97 \pm \\
0.08\end{array}$ & $\begin{array}{c}1.00 \pm \\
0.00\end{array}$ & $\begin{array}{c}1.00 \pm \\
0.00\end{array}$ & $\begin{array}{c}1.00 \pm \\
0.00\end{array}$ & $\begin{array}{c}1.00 \pm \\
0.00\end{array}$ & $\begin{array}{c}0.91 \pm \\
0.12\end{array}$ & $\begin{array}{c}0.94 \pm \\
0.17\end{array}$ & $\begin{array}{c}0.88 \pm \\
0.22\end{array}$ & $\begin{array}{c}0.91 \pm \\
0.12\end{array}$ \\
\hline 0.66 & $\begin{array}{c}0.97 \pm \\
0.08\end{array}$ & $\begin{array}{c}1.00 \pm \\
0.00\end{array}$ & $\begin{array}{c}0.94 \pm \\
0.17\end{array}$ & $\begin{array}{c}0.97 \pm \\
0.08\end{array}$ & $\begin{array}{c}0.97 \pm \\
0.08\end{array}$ & $\begin{array}{c}1.00 \pm \\
0.00\end{array}$ & $\begin{array}{c}0.94 \pm \\
0.17\end{array}$ & $\begin{array}{c}0.97 \pm \\
0.08\end{array}$ & $\begin{array}{c}0.97 \pm \\
0.08\end{array}$ & $\begin{array}{c}0.94 \pm \\
0.17\end{array}$ & $\begin{array}{c}1.00 \pm \\
0.00\end{array}$ & $\begin{array}{c}0.97 \pm \\
0.08\end{array}$ & $\begin{array}{c}0.94 \pm \\
0.11\end{array}$ & $\begin{array}{c}1.00 \pm \\
0.00\end{array}$ & $\begin{array}{c}0.88 \pm \\
0.22\end{array}$ & $\begin{array}{c}0.94 \pm \\
0.11\end{array}$ \\
\hline 0.67 & $\begin{array}{c}0.97 \pm \\
0.08\end{array}$ & $\begin{array}{c}1.00 \pm \\
0.00\end{array}$ & $\begin{array}{c}0.94 \pm \\
0.17\end{array}$ & $\begin{array}{c}0.97 \pm \\
0.08\end{array}$ & $\begin{array}{c}0.94 \pm \\
0.17\end{array}$ & $\begin{array}{c}0.94 \pm \\
0.17\end{array}$ & $\begin{array}{c}0.94 \pm \\
0.17\end{array}$ & $\begin{array}{c}0.94 \pm \\
0.17 \\
\end{array}$ & $\begin{array}{c}0.97 \pm \\
0.08 \\
\end{array}$ & $\begin{array}{c}0.94 \pm \\
0.17 \\
\end{array}$ & $\begin{array}{c}1.00 \pm \\
0.00 \\
\end{array}$ & $\begin{array}{c}0.97 \pm \\
0.08 \\
\end{array}$ & $\begin{array}{c}0.94 \pm \\
0.17 \\
\end{array}$ & $\begin{array}{c}1.00 \pm \\
0.00 \\
\end{array}$ & $\begin{array}{c}0.97 \pm \\
0.08 \\
\end{array}$ & $\begin{array}{c}0.94 \pm \\
0.11 \\
\end{array}$ \\
\hline
\end{tabular}




\begin{tabular}{|c|c|c|c|c|c|c|c|c|c|c|c|c|c|c|c|c|}
\hline \multirow{2}{*}{$\begin{array}{l}\text { Threshold } \\
\text { (28: 1068) }\end{array}$} & \multicolumn{4}{|c|}{ SVM } & \multicolumn{4}{|c|}{ Random Forest } & \multicolumn{4}{|c|}{ Naive Bayes } & \multicolumn{4}{|c|}{ CatBoost } \\
\hline & Accuracy & Spec & SEN & AUC & Accuracy & Spec & SEN & AUC & Accuracy & Spec & SEN & AUC & Accuracy & Spec & SEN & AUC \\
\hline 0.68 & $\begin{array}{c}0.97 \pm \\
0.08\end{array}$ & $\begin{array}{c}1.00 \pm \\
0.00\end{array}$ & $\begin{array}{c}0.94 \pm \\
0.17\end{array}$ & $\begin{array}{c}0.97 \pm \\
0.08\end{array}$ & $\begin{array}{c}0.94 \pm \\
0.17\end{array}$ & $\begin{array}{c}0.94 \pm \\
0.17\end{array}$ & $\begin{array}{c}0.94 \pm \\
0.17\end{array}$ & $\begin{array}{c}0.94 \pm \\
0.17\end{array}$ & $\begin{array}{c}0.97 \pm \\
0.08\end{array}$ & $\begin{array}{c}0.94 \pm \\
0.17\end{array}$ & $\begin{array}{c}1.00 \pm \\
0.00\end{array}$ & $\begin{array}{c}0.97 \pm \\
0.08\end{array}$ & $\begin{array}{c}0.94 \pm \\
0.11\end{array}$ & $\begin{array}{c}1.00 \pm \\
0.00\end{array}$ & $\begin{array}{c}0.88 \pm \\
0.22\end{array}$ & $\begin{array}{c}0.94 \pm \\
0.11\end{array}$ \\
\hline 0.69 & $\begin{array}{c}0.97 \pm \\
0.08\end{array}$ & $\begin{array}{c}1.00 \pm \\
0.00\end{array}$ & $\begin{array}{c}0.94 \pm \\
0.17\end{array}$ & $\begin{array}{c}0.97 \pm \\
0.08\end{array}$ & $\begin{array}{c}0.91 \pm \\
0.17\end{array}$ & $\begin{array}{c}0.94 \pm \\
0.17\end{array}$ & $\begin{array}{c}0.88 \pm \\
0.22\end{array}$ & $\begin{array}{c}0.91 \pm \\
0.17\end{array}$ & $\begin{array}{c}0.97 \pm \\
0.08\end{array}$ & $\begin{array}{c}0.94 \pm \\
0.17\end{array}$ & $\begin{array}{c}1.00 \pm \\
0.00\end{array}$ & $\begin{array}{c}0.97 \pm \\
0.08\end{array}$ & $\begin{array}{c}0.94 \pm \\
0.11\end{array}$ & $\begin{array}{c}1.00 \pm \\
0.00\end{array}$ & $\begin{array}{c}0.88 \pm \\
0.22\end{array}$ & $\begin{array}{c}0.94 \pm \\
0.11\end{array}$ \\
\hline 0.7 & $\begin{array}{c}0.94 \pm \\
0.11\end{array}$ & $\begin{array}{c}1.00 \pm \\
0.00\end{array}$ & $\begin{array}{c}0.88 \pm \\
0.22\end{array}$ & $\begin{array}{c}0.94 \pm \\
0.11\end{array}$ & $\begin{array}{c}0.91 \pm \\
0.17\end{array}$ & $\begin{array}{c}0.94 \pm \\
0.17\end{array}$ & $\begin{array}{c}0.88 \pm \\
0.22\end{array}$ & $\begin{array}{c}0.91 \pm \\
0.17\end{array}$ & $\begin{array}{c}0.91 \pm \\
0.12\end{array}$ & $\begin{array}{c}0.81 \pm \\
0.24\end{array}$ & $\begin{array}{c}1.00 \pm \\
0.00\end{array}$ & $\begin{array}{c}0.91 \pm \\
0.12\end{array}$ & $\begin{array}{c}0.94 \pm \\
0.11\end{array}$ & $\begin{array}{c}1.00 \pm \\
0.00\end{array}$ & $\begin{array}{c}0.88 \pm \\
0.22\end{array}$ & $\begin{array}{c}0.94 \pm \\
0.11\end{array}$ \\
\hline 0.71 & $\begin{array}{c}0.94 \pm \\
0.11\end{array}$ & $\begin{array}{c}1.00 \pm \\
0.00\end{array}$ & $\begin{array}{c}0.88 \pm \\
0.22\end{array}$ & $\begin{array}{c}0.94 \pm \\
0.11\end{array}$ & $\begin{array}{c}0.91 \pm \\
0.17\end{array}$ & $\begin{array}{c}0.94 \pm \\
0.17\end{array}$ & $\begin{array}{c}0.88 \pm \\
0.22\end{array}$ & $\begin{array}{c}0.91 \pm \\
0.17\end{array}$ & $\begin{array}{c}0.93 \pm \\
0.13\end{array}$ & $\begin{array}{c}0.88 \pm \\
0.22\end{array}$ & $\begin{array}{c}1.00 \pm \\
0.00\end{array}$ & $\begin{array}{c}0.94 \pm \\
0.11\end{array}$ & $\begin{array}{c}0.91 \pm \\
0.12\end{array}$ & $\begin{array}{c}0.94 \pm \\
0.17\end{array}$ & $\begin{array}{c}0.81 \pm \\
0.24\end{array}$ & $\begin{array}{c}0.91 \pm \\
0.12\end{array}$ \\
\hline 0.72 & $\begin{array}{c}0.94 \pm \\
0.11\end{array}$ & $\begin{array}{c}1.00 \pm \\
0.00\end{array}$ & $\begin{array}{c}0.88 \pm \\
0.22\end{array}$ & $\begin{array}{c}0.94 \pm \\
0.11\end{array}$ & $\begin{array}{c}0.97 \pm \\
0.08\end{array}$ & $\begin{array}{c}1.00 \pm \\
0.00\end{array}$ & $\begin{array}{c}0.94 \pm \\
0.17\end{array}$ & $\begin{array}{c}0.97 \pm \\
0.08\end{array}$ & $\begin{array}{c}0.90 \pm \\
0.14\end{array}$ & $\begin{array}{c}0.88 \pm \\
0.22\end{array}$ & $\begin{array}{c}0.94 \pm \\
0.17\end{array}$ & $\begin{array}{c}0.91 \pm \\
0.12\end{array}$ & $\begin{array}{c}0.91 \pm \\
0.12\end{array}$ & $\begin{array}{c}1.00 \pm \\
0.00\end{array}$ & $\begin{array}{c}0.81 \pm \\
0.24\end{array}$ & $\begin{array}{c}0.91 \pm \\
0.12\end{array}$ \\
\hline 0.73 & $\begin{array}{c}0.94 \pm \\
0.11\end{array}$ & $\begin{array}{c}1.00 \pm \\
0.00\end{array}$ & $\begin{array}{c}0.88 \pm \\
0.22\end{array}$ & $\begin{array}{c}0.94 \pm \\
0.11\end{array}$ & $\begin{array}{c}0.94 \pm \\
0.17\end{array}$ & $\begin{array}{c}0.94 \pm \\
0.17\end{array}$ & $\begin{array}{c}0.94 \pm \\
0.17\end{array}$ & $\begin{array}{c}0.94 \pm \\
0.17\end{array}$ & $\begin{array}{c}0.90 \pm \\
0.14\end{array}$ & $\begin{array}{c}0.88 \pm \\
0.22\end{array}$ & $\begin{array}{c}0.94 \pm \\
0.17\end{array}$ & $\begin{array}{c}0.91 \pm \\
0.12\end{array}$ & $\begin{array}{c}0.91 \pm \\
0.12\end{array}$ & $\begin{array}{c}1.00 \pm \\
0.00\end{array}$ & $\begin{array}{c}0.81 \pm \\
0.24\end{array}$ & $\begin{array}{c}0.91 \pm \\
0.12\end{array}$ \\
\hline 0.74 & $\begin{array}{c}0.97 \pm \\
0.08\end{array}$ & $\begin{array}{c}1.00 \pm \\
0.00\end{array}$ & $\begin{array}{c}0.94 \pm \\
0.17\end{array}$ & $\begin{array}{c}0.97 \pm \\
0.08\end{array}$ & $\begin{array}{c}0.91 \pm \\
0.17 \\
\end{array}$ & $\begin{array}{c}0.94 \pm \\
0.17\end{array}$ & $\begin{array}{c}0.88 \pm \\
0.22 \\
\end{array}$ & $\begin{array}{c}0.91 \pm \\
0.17\end{array}$ & $\begin{array}{c}0.93 \pm \\
0.13\end{array}$ & $\begin{array}{c}0.88 \pm \\
0.22 \\
\end{array}$ & $\begin{array}{c}1.00 \pm \\
0.00\end{array}$ & $\begin{array}{c}0.94 \pm \\
0.11\end{array}$ & $\begin{array}{c}0.94 \pm \\
0.11 \\
\end{array}$ & $\begin{array}{c}1.00 \pm \\
0.00\end{array}$ & $\begin{array}{c}0.88 \pm \\
0.22\end{array}$ & $\begin{array}{c}0.94 \pm \\
0.11 \\
\end{array}$ \\
\hline 0.75 & $\begin{array}{c}0.97 \pm \\
0.08\end{array}$ & $\begin{array}{c}1.00 \pm \\
0.00\end{array}$ & $\begin{array}{c}0.94 \pm \\
0.17\end{array}$ & $\begin{array}{c}0.97 \pm \\
0.08\end{array}$ & $\begin{array}{c}0.97 \pm \\
0.08\end{array}$ & $\begin{array}{c}1.00 \pm \\
0.00\end{array}$ & $\begin{array}{c}0.94 \pm \\
0.17\end{array}$ & $\begin{array}{c}0.97 \pm \\
0.08\end{array}$ & $\begin{array}{c}0.90 \pm \\
0.14\end{array}$ & $\begin{array}{c}0.88 \pm \\
0.22\end{array}$ & $\begin{array}{c}0.94 \pm \\
0.17\end{array}$ & $\begin{array}{c}0.91 \pm \\
0.12\end{array}$ & $\begin{array}{c}0.94 \pm \\
0.11\end{array}$ & $\begin{array}{c}1.00 \pm \\
0.00\end{array}$ & $\begin{array}{c}0.88 \pm \\
0.22\end{array}$ & $\begin{array}{c}0.94 \pm \\
0.11\end{array}$ \\
\hline 0.76 & $\begin{array}{c}0.97 \pm \\
0.08\end{array}$ & $\begin{array}{c}1.00 \pm \\
0.00\end{array}$ & $\begin{array}{c}0.94 \pm \\
0.17\end{array}$ & $\begin{array}{c}0.97 \pm \\
0.08\end{array}$ & $\begin{array}{c}0.94 \pm \\
0.17\end{array}$ & $\begin{array}{c}0.94 \pm \\
0.17\end{array}$ & $\begin{array}{c}0.94 \pm \\
0.17\end{array}$ & $\begin{array}{c}0.94 \pm \\
0.17\end{array}$ & $\begin{array}{c}0.80 \pm \\
0.21\end{array}$ & $\begin{array}{c}0.75 \pm \\
0.35\end{array}$ & $\begin{array}{c}0.88 \pm \\
0.22\end{array}$ & $\begin{array}{c}0.81 \pm \\
0.21\end{array}$ & $\begin{array}{c}0.94 \pm \\
0.11\end{array}$ & $\begin{array}{c}1.00 \pm \\
0.00\end{array}$ & $\begin{array}{c}0.88 \pm \\
0.22\end{array}$ & $\begin{array}{c}0.94 \pm \\
0.11\end{array}$ \\
\hline 0.77 & $\begin{array}{c}0.97 \pm \\
0.08\end{array}$ & $\begin{array}{c}1.00 \pm \\
0.00\end{array}$ & $\begin{array}{c}0.94 \pm \\
0.17\end{array}$ & $\begin{array}{c}0.97 \pm \\
0.08\end{array}$ & $\begin{array}{c}0.93 \pm \\
0.13\end{array}$ & $\begin{array}{c}0.94 \pm \\
0.17\end{array}$ & $\begin{array}{c}0.94 \pm \\
0.17\end{array}$ & $\begin{array}{c}0.94 \pm \\
0.11\end{array}$ & $\begin{array}{c}0.80 \pm \\
0.21\end{array}$ & $\begin{array}{c}0.75 \pm \\
0.35\end{array}$ & $\begin{array}{c}0.88 \pm \\
0.22\end{array}$ & $\begin{array}{c}0.81 \pm \\
0.21\end{array}$ & $\begin{array}{c}0.94 \pm \\
0.11\end{array}$ & $\begin{array}{c}1.00 \pm \\
0.00\end{array}$ & $\begin{array}{c}0.88 \pm \\
0.22\end{array}$ & $\begin{array}{c}0.94 \pm \\
0.11\end{array}$ \\
\hline 0.78 & $\begin{array}{c}0.97 \pm \\
0.08\end{array}$ & $\begin{array}{c}1.00 \pm \\
0.00\end{array}$ & $\begin{array}{c}0.94 \pm \\
0.17\end{array}$ & $\begin{array}{c}0.97 \pm \\
0.08\end{array}$ & $\begin{array}{c}0.86 \pm \\
0.19\end{array}$ & $\begin{array}{c}0.88 \pm \\
0.22\end{array}$ & $\begin{array}{c}0.88 \pm \\
0.22\end{array}$ & $\begin{array}{c}0.88 \pm \\
0.18\end{array}$ & $\begin{array}{c}0.83 \pm \\
0.18\end{array}$ & $\begin{array}{c}0.75 \pm \\
0.35\end{array}$ & $\begin{array}{c}0.94 \pm \\
0.17\end{array}$ & $\begin{array}{c}0.84 \pm \\
0.17\end{array}$ & $\begin{array}{c}0.94 \pm \\
0.11\end{array}$ & $\begin{array}{c}1.00 \pm \\
0.00\end{array}$ & $\begin{array}{c}0.88 \pm \\
0.22\end{array}$ & $\begin{array}{c}0.94 \pm \\
0.11\end{array}$ \\
\hline 0.79 & $\begin{array}{c}1.00 \pm \\
0.00\end{array}$ & $\begin{array}{c}1.00 \pm \\
0.00\end{array}$ & $\begin{array}{c}1.00 \pm \\
0.00\end{array}$ & $\begin{array}{c}1.00 \pm \\
0.00\end{array}$ & $\begin{array}{c}0.90 \pm \\
0.19\end{array}$ & $\begin{array}{c}0.88 \pm \\
0.22\end{array}$ & $\begin{array}{c}0.94 \pm \\
0.17\end{array}$ & $\begin{array}{c}0.91 \pm \\
0.17\end{array}$ & $\begin{array}{c}0.83 \pm \\
0.18\end{array}$ & $\begin{array}{c}0.75 \pm \\
0.35\end{array}$ & $\begin{array}{c}0.94 \pm \\
0.17\end{array}$ & $\begin{array}{c}0.84 \pm \\
0.17\end{array}$ & $\begin{array}{c}0.94 \pm \\
0.11\end{array}$ & $\begin{array}{c}1.00 \pm \\
0.00\end{array}$ & $\begin{array}{c}0.88 \pm \\
0.22\end{array}$ & $\begin{array}{c}0.94 \pm \\
0.11\end{array}$ \\
\hline 0.8 & $\begin{array}{c}1.00 \pm \\
0.00\end{array}$ & $\begin{array}{c}1.00 \pm \\
0.00\end{array}$ & $\begin{array}{c}1.00 \pm \\
0.00\end{array}$ & $\begin{array}{c}1.00 \pm \\
0.00\end{array}$ & $\begin{array}{c}0.94 \pm \\
0.11\end{array}$ & $\begin{array}{c}1.00 \pm \\
0.00\end{array}$ & $\begin{array}{c}0.88 \pm \\
0.22\end{array}$ & $\begin{array}{c}0.94 \pm \\
0.11\end{array}$ & $\begin{array}{c}0.86 \pm \\
0.14\end{array}$ & $\begin{array}{c}0.75 \pm \\
0.35\end{array}$ & $\begin{array}{c}0.94 \pm \\
0.17\end{array}$ & $\begin{array}{c}0.84 \pm \\
0.17\end{array}$ & $\begin{array}{c}0.94 \pm \\
0.11\end{array}$ & $\begin{array}{c}1.00 \pm \\
0.00\end{array}$ & $\begin{array}{c}0.88 \pm \\
0.22\end{array}$ & $\begin{array}{c}0.94 \pm \\
0.11\end{array}$ \\
\hline 0.81 & $\begin{array}{c}1.00 \pm \\
0.00\end{array}$ & $\begin{array}{c}1.00 \pm \\
0.00\end{array}$ & $\begin{array}{c}1.00 \pm \\
0.00\end{array}$ & $\begin{array}{c}1.00 \pm \\
0.00\end{array}$ & $\begin{array}{c}0.97 \pm \\
0.08\end{array}$ & $\begin{array}{c}1.00 \pm \\
0.00\end{array}$ & $\begin{array}{c}0.94 \pm \\
0.17\end{array}$ & $\begin{array}{c}0.97 \pm \\
0.08\end{array}$ & $\begin{array}{c}0.83 \pm \\
0.19\end{array}$ & $\begin{array}{c}0.81 \pm \\
0.24\end{array}$ & $\begin{array}{c}0.94 \pm \\
0.17\end{array}$ & $\begin{array}{c}0.88 \pm \\
0.18\end{array}$ & $\begin{array}{c}0.90 \pm \\
0.14\end{array}$ & $\begin{array}{c}0.94 \pm \\
0.17\end{array}$ & $\begin{array}{c}0.88 \pm \\
0.22\end{array}$ & $\begin{array}{c}0.91 \pm \\
0.12\end{array}$ \\
\hline 0.82 & $\begin{array}{c}1.00 \pm \\
0.00\end{array}$ & $\begin{array}{c}1.00 \pm \\
0.00\end{array}$ & $\begin{array}{c}1.00 \pm \\
0.00\end{array}$ & $\begin{array}{c}1.00 \pm \\
0.00\end{array}$ & $\begin{array}{c}0.93 \pm \\
0.13\end{array}$ & $\begin{array}{c}0.94 \pm \\
0.17\end{array}$ & $\begin{array}{c}0.94 \pm \\
0.17\end{array}$ & $\begin{array}{c}0.94 \pm \\
0.11\end{array}$ & $\begin{array}{c}0.86 \pm \\
0.19\end{array}$ & $\begin{array}{c}0.81 \pm \\
0.24\end{array}$ & $\begin{array}{c}0.94 \pm \\
0.17\end{array}$ & $\begin{array}{c}0.88 \pm \\
0.18\end{array}$ & $\begin{array}{c}0.90 \pm \\
0.14\end{array}$ & $\begin{array}{c}0.94 \pm \\
0.17\end{array}$ & $\begin{array}{c}0.88 \pm \\
0.22\end{array}$ & $\begin{array}{c}0.91 \pm \\
0.12\end{array}$ \\
\hline 0.83 & $\begin{array}{c}1.00 \pm \\
0.00\end{array}$ & $\begin{array}{c}1.00 \pm \\
0.00\end{array}$ & $\begin{array}{c}1.00 \pm \\
0.00\end{array}$ & $\begin{array}{c}1.00 \pm \\
0.00\end{array}$ & $\begin{array}{c}0.97 \pm \\
0.08\end{array}$ & $\begin{array}{c}1.00 \pm \\
0.00\end{array}$ & $\begin{array}{c}0.94 \pm \\
0.17\end{array}$ & $\begin{array}{c}0.97 \pm \\
0.08\end{array}$ & $\begin{array}{c}0.90 \pm \\
0.14\end{array}$ & $\begin{array}{c}0.81 \pm \\
0.24\end{array}$ & $\begin{array}{c}1.00 \pm \\
0.00\end{array}$ & $\begin{array}{c}0.91 \pm \\
0.12\end{array}$ & $\begin{array}{c}0.93 \pm \\
0.13\end{array}$ & $\begin{array}{c}0.94 \pm \\
0.17\end{array}$ & $\begin{array}{c}0.94 \pm \\
0.17\end{array}$ & $\begin{array}{c}0.94 \pm \\
0.11\end{array}$ \\
\hline 0.84 & $\begin{array}{c}1.00 \pm \\
0.00\end{array}$ & $\begin{array}{c}1.00 \pm \\
0.00\end{array}$ & $\begin{array}{c}1.00 \pm \\
0.00\end{array}$ & $\begin{array}{c}1.00 \pm \\
0.00\end{array}$ & $\begin{array}{c}0.97 \pm \\
0.08\end{array}$ & $\begin{array}{c}1.00 \pm \\
0.00\end{array}$ & $\begin{array}{c}0.94 \pm \\
0.17\end{array}$ & $\begin{array}{c}0.97 \pm \\
0.08\end{array}$ & $\begin{array}{c}0.90 \pm \\
0.14\end{array}$ & $\begin{array}{c}0.81 \pm \\
0.24\end{array}$ & $\begin{array}{c}1.00 \pm \\
0.00\end{array}$ & $\begin{array}{c}0.91 \pm \\
0.12\end{array}$ & $\begin{array}{c}0.97 \pm \\
0.08\end{array}$ & $\begin{array}{c}1.00 \pm \\
0.00\end{array}$ & $\begin{array}{c}0.94 \pm \\
0.17\end{array}$ & $\begin{array}{c}0.97 \pm \\
0.08\end{array}$ \\
\hline 0.85 & $\begin{array}{c}0.97 \pm \\
0.08\end{array}$ & $\begin{array}{c}1.00 \pm \\
0.00\end{array}$ & $\begin{array}{c}0.94 \pm \\
0.17\end{array}$ & $\begin{array}{c}0.97 \pm \\
0.08\end{array}$ & $\begin{array}{c}0.93 \pm \\
0.13\end{array}$ & $\begin{array}{c}0.94 \pm \\
0.17\end{array}$ & $\begin{array}{c}0.94 \pm \\
0.17\end{array}$ & $\begin{array}{c}0.94 \pm \\
0.11\end{array}$ & $\begin{array}{c}0.90 \pm \\
0.14\end{array}$ & $\begin{array}{c}0.81 \pm \\
0.24\end{array}$ & $\begin{array}{c}1.00 \pm \\
0.00\end{array}$ & $\begin{array}{c}0.91 \pm \\
0.12\end{array}$ & $\begin{array}{c}0.97 \pm \\
0.08\end{array}$ & $\begin{array}{c}1.00 \pm \\
0.00\end{array}$ & $\begin{array}{c}0.94 \pm \\
0.17\end{array}$ & $\begin{array}{c}0.97 \pm \\
0.08\end{array}$ \\
\hline 0.86 & $\begin{array}{c}0.97 \pm \\
0.08\end{array}$ & $\begin{array}{c}1.00 \pm \\
0.00\end{array}$ & $\begin{array}{c}0.94 \pm \\
0.17\end{array}$ & $\begin{array}{c}0.97 \pm \\
0.08\end{array}$ & $\begin{array}{c}0.97 \pm \\
0.08\end{array}$ & $\begin{array}{c}1.00 \pm \\
0.00\end{array}$ & $\begin{array}{c}0.94 \pm \\
0.17\end{array}$ & $\begin{array}{c}0.97 \pm \\
0.08\end{array}$ & $\begin{array}{c}0.90 \pm \\
0.14\end{array}$ & $\begin{array}{c}0.81 \pm \\
0.24\end{array}$ & $\begin{array}{c}1.00 \pm \\
0.00\end{array}$ & $\begin{array}{c}0.91 \pm \\
0.12\end{array}$ & $\begin{array}{c}0.93 \pm \\
0.13\end{array}$ & $\begin{array}{c}0.94 \pm \\
0.17\end{array}$ & $\begin{array}{c}0.94 \pm \\
0.17\end{array}$ & $\begin{array}{c}0.94 \pm \\
0.11\end{array}$ \\
\hline 0.87 & $\begin{array}{c}0.97 \pm \\
0.08\end{array}$ & $\begin{array}{c}1.00 \pm \\
0.00\end{array}$ & $\begin{array}{c}0.94 \pm \\
0.17\end{array}$ & $\begin{array}{c}0.97 \pm \\
0.08\end{array}$ & $\begin{array}{c}0.97 \pm \\
0.08\end{array}$ & $\begin{array}{c}1.00 \pm \\
0.00\end{array}$ & $\begin{array}{c}0.94 \pm \\
0.17\end{array}$ & $\begin{array}{c}0.97 \pm \\
0.08\end{array}$ & $\begin{array}{c}0.90 \pm \\
0.14\end{array}$ & $\begin{array}{c}0.81 \pm \\
0.24\end{array}$ & $\begin{array}{c}1.00 \pm \\
0.00\end{array}$ & $\begin{array}{c}0.91 \pm \\
0.12\end{array}$ & $\begin{array}{c}0.93 \pm \\
0.13\end{array}$ & $\begin{array}{c}0.94 \pm \\
0.17\end{array}$ & $\begin{array}{c}0.94 \pm \\
0.17\end{array}$ & $\begin{array}{c}0.94 \pm \\
0.11\end{array}$ \\
\hline
\end{tabular}




\begin{tabular}{|c|c|c|c|c|c|c|c|c|c|c|c|c|c|c|c|c|}
\hline \multirow{2}{*}{$\begin{array}{l}\text { Threshold } \\
\text { (28: 1068) }\end{array}$} & \multicolumn{4}{|c|}{ SVM } & \multicolumn{4}{|c|}{ Random Forest } & \multicolumn{4}{|c|}{ Naive Bayes } & \multicolumn{4}{|c|}{ CatBoost } \\
\hline & Accuracy & Spec & SEN & AUC & Accuracy & Spec & SEN & AUC & Accuracy & Spec & SEN & AUC & Accuracy & Spec & SEN & AUC \\
\hline 0.88 & $\begin{array}{c}0.97 \pm \\
0.08\end{array}$ & $\begin{array}{c}1.00 \pm \\
0.00\end{array}$ & $\begin{array}{c}0.94 \pm \\
0.17\end{array}$ & $\begin{array}{c}0.97 \pm \\
0.08\end{array}$ & $\begin{array}{c}0.97 \pm \\
0.08\end{array}$ & $\begin{array}{c}1.00 \pm \\
0.00\end{array}$ & $\begin{array}{c}0.94 \pm \\
0.17\end{array}$ & $\begin{array}{c}0.97 \pm \\
0.08\end{array}$ & $\begin{array}{c}0.90 \pm \\
0.14\end{array}$ & $\begin{array}{l}0.81 \pm \\
0.24\end{array}$ & $\begin{array}{c}1.00 \pm \\
0.00\end{array}$ & $\begin{array}{c}0.91 \pm \\
0.12\end{array}$ & $\begin{array}{c}0.93 \pm \\
0.13\end{array}$ & $\begin{array}{c}0.94 \pm \\
0.17\end{array}$ & $\begin{array}{c}0.94 \pm \\
0.17\end{array}$ & $\begin{array}{c}0.94 \pm \\
0.11\end{array}$ \\
\hline 0.89 & $\begin{array}{c}0.97 \pm \\
0.08\end{array}$ & $\begin{array}{c}1.00 \pm \\
0.00\end{array}$ & $\begin{array}{c}0.94 \pm \\
0.17\end{array}$ & $\begin{array}{c}0.97 \pm \\
0.08\end{array}$ & $\begin{array}{c}0.94 \pm \\
0.11\end{array}$ & $\begin{array}{c}1.00 \pm \\
0.00\end{array}$ & $\begin{array}{c}0.88 \pm \\
0.22\end{array}$ & $\begin{array}{c}0.94 \pm \\
0.11\end{array}$ & $\begin{array}{c}0.90 \pm \\
0.14\end{array}$ & $\begin{array}{c}0.81 \pm \\
0.24\end{array}$ & $\begin{array}{c}1.00 \pm \\
0.00\end{array}$ & $\begin{array}{c}0.91 \pm \\
0.12\end{array}$ & $\begin{array}{c}0.97 \pm \\
0.08\end{array}$ & $\begin{array}{c}1.00 \pm \\
0.00\end{array}$ & $\begin{array}{c}0.94 \pm \\
0.17\end{array}$ & $\begin{array}{c}0.97 \pm \\
0.08\end{array}$ \\
\hline 0.9 & $\begin{array}{c}0.97 \pm \\
0.08\end{array}$ & $\begin{array}{c}1.00 \pm \\
0.00\end{array}$ & $\begin{array}{c}0.94 \pm \\
0.17\end{array}$ & $\begin{array}{c}0.97 \pm \\
0.08\end{array}$ & $\begin{array}{c}0.93 \pm \\
0.13\end{array}$ & $\begin{array}{c}0.94 \pm \\
0.17\end{array}$ & $\begin{array}{c}0.94 \pm \\
0.17\end{array}$ & $\begin{array}{c}0.94 \pm \\
0.11\end{array}$ & $\begin{array}{c}0.90 \pm \\
0.14\end{array}$ & $\begin{array}{l}0.81 \pm \\
0.24\end{array}$ & $\begin{array}{c}1.00 \pm \\
0.00\end{array}$ & $\begin{array}{c}0.91 \pm \\
0.12\end{array}$ & $\begin{array}{c}0.97 \pm \\
0.08\end{array}$ & $\begin{array}{c}1.00 \pm \\
0.00\end{array}$ & $\begin{array}{c}0.94 \pm \\
0.17\end{array}$ & $\begin{array}{c}0.97 \pm \\
0.08\end{array}$ \\
\hline 0.91 & $\begin{array}{c}0.97 \pm \\
0.08\end{array}$ & $\begin{array}{c}1.00 \pm \\
0.00\end{array}$ & $\begin{array}{c}0.94 \pm \\
0.17\end{array}$ & $\begin{array}{c}0.97 \pm \\
0.08\end{array}$ & $\begin{array}{c}0.90 \pm \\
0.14\end{array}$ & $\begin{array}{c}0.81 \pm \\
0.24\end{array}$ & $\begin{array}{c}1.00 \pm \\
0.00\end{array}$ & $\begin{array}{c}0.91 \pm \\
0.12\end{array}$ & $\begin{array}{c}0.90 \pm \\
0.14\end{array}$ & $\begin{array}{c}0.81 \pm \\
0.24\end{array}$ & $\begin{array}{c}1.00 \pm \\
0.00\end{array}$ & $\begin{array}{c}0.91 \pm \\
0.12\end{array}$ & $\begin{array}{c}0.97 \pm \\
0.08\end{array}$ & $\begin{array}{c}1.00 \pm \\
0.00\end{array}$ & $\begin{array}{c}0.94 \pm \\
0.17\end{array}$ & $\begin{array}{c}0.97 \pm \\
0.08\end{array}$ \\
\hline 0.92 & $\begin{array}{c}0.97 \pm \\
0.08\end{array}$ & $\begin{array}{c}1.00 \pm \\
0.00\end{array}$ & $\begin{array}{c}0.94 \pm \\
0.17\end{array}$ & $\begin{array}{c}0.97 \pm \\
0.08\end{array}$ & $\begin{array}{c}0.93 \pm \\
0.13\end{array}$ & $\begin{array}{c}0.94 \pm \\
0.17\end{array}$ & $\begin{array}{c}0.94 \pm \\
0.17\end{array}$ & $\begin{array}{c}0.94 \pm \\
0.11\end{array}$ & $\begin{array}{c}0.83 \pm \\
0.18\end{array}$ & $\begin{array}{c}0.69 \pm \\
0.35\end{array}$ & $\begin{array}{c}1.00 \pm \\
0.00\end{array}$ & $\begin{array}{c}0.84 \pm \\
0.17\end{array}$ & $\begin{array}{c}0.97 \pm \\
0.08\end{array}$ & $\begin{array}{c}1.00 \pm \\
0.00\end{array}$ & $\begin{array}{c}0.94 \pm \\
0.17\end{array}$ & $\begin{array}{c}0.97 \pm \\
0.08\end{array}$ \\
\hline 0.93 & $\begin{array}{c}0.97 \pm \\
0.08\end{array}$ & $\begin{array}{c}1.00 \pm \\
0.00\end{array}$ & $\begin{array}{c}0.94 \pm \\
0.17\end{array}$ & $\begin{array}{c}0.97 \pm \\
0.08\end{array}$ & $\begin{array}{c}0.90 \pm \\
0.14\end{array}$ & $\begin{array}{c}0.94 \pm \\
0.17\end{array}$ & $\begin{array}{c}0.88 \pm \\
0.22\end{array}$ & $\begin{array}{c}0.91 \pm \\
0.12\end{array}$ & $\begin{array}{c}0.83 \pm \\
0.18\end{array}$ & $\begin{array}{c}0.69 \pm \\
0.35\end{array}$ & $\begin{array}{c}1.00 \pm \\
0.00\end{array}$ & $\begin{array}{c}0.84 \pm \\
0.17\end{array}$ & $\begin{array}{c}0.97 \pm \\
0.08\end{array}$ & $\begin{array}{c}1.00 \pm \\
0.00\end{array}$ & $\begin{array}{c}0.94 \pm \\
0.17\end{array}$ & $\begin{array}{c}0.97 \pm \\
0.08\end{array}$ \\
\hline 0.94 & $\begin{array}{c}0.97 \pm \\
0.08\end{array}$ & $\begin{array}{c}1.00 \pm \\
0.00\end{array}$ & $\begin{array}{c}0.94 \pm \\
0.17\end{array}$ & $\begin{array}{c}0.97 \pm \\
0.08\end{array}$ & $\begin{array}{c}0.93 \pm \\
0.13\end{array}$ & $\begin{array}{c}0.94 \pm \\
0.17\end{array}$ & $\begin{array}{c}0.94 \pm \\
0.17\end{array}$ & $\begin{array}{c}0.94 \pm \\
0.11\end{array}$ & $\begin{array}{c}0.83 \pm \\
0.18\end{array}$ & $\begin{array}{c}0.69 \pm \\
0.35\end{array}$ & $\begin{array}{c}1.00 \pm \\
0.00\end{array}$ & $\begin{array}{c}0.84 \pm \\
0.17\end{array}$ & $\begin{array}{c}0.97 \pm \\
0.08\end{array}$ & $\begin{array}{c}1.00 \pm \\
0.00\end{array}$ & $\begin{array}{c}0.94 \pm \\
0.17\end{array}$ & $\begin{array}{c}0.97 \pm \\
0.08\end{array}$ \\
\hline 0.95 & $\begin{array}{c}0.97 \pm \\
0.08\end{array}$ & $\begin{array}{c}1.00 \pm \\
0.00\end{array}$ & $\begin{array}{c}0.94 \pm \\
0.17\end{array}$ & $\begin{array}{c}0.97 \pm \\
0.08\end{array}$ & $\begin{array}{c}0.97 \pm \\
0.08\end{array}$ & $\begin{array}{c}1.00 \pm \\
0.00\end{array}$ & $\begin{array}{c}0.94 \pm \\
0.17\end{array}$ & $\begin{array}{c}0.97 \pm \\
0.08\end{array}$ & $\begin{array}{c}0.83 \pm \\
0.18\end{array}$ & $\begin{array}{c}0.69 \pm \\
0.35\end{array}$ & $\begin{array}{c}1.00 \pm \\
0.00\end{array}$ & $\begin{array}{c}0.84 \pm \\
0.17\end{array}$ & $\begin{array}{c}0.97 \pm \\
0.08\end{array}$ & $\begin{array}{c}1.00 \pm \\
0.00\end{array}$ & $\begin{array}{c}0.94 \pm \\
0.17\end{array}$ & $\begin{array}{c}0.97 \pm \\
0.08\end{array}$ \\
\hline 0.96 & $\begin{array}{c}0.97 \pm \\
0.08\end{array}$ & $\begin{array}{c}1.00 \pm \\
0.00\end{array}$ & $\begin{array}{c}0.94 \pm \\
0.17\end{array}$ & $\begin{array}{c}0.97 \pm \\
0.08\end{array}$ & $\begin{array}{c}0.97 \pm \\
0.08\end{array}$ & $\begin{array}{c}1.00 \pm \\
0.00\end{array}$ & $\begin{array}{c}0.94 \pm \\
0.17\end{array}$ & $\begin{array}{c}0.97 \pm \\
0.08\end{array}$ & $\begin{array}{c}0.83 \pm \\
0.18\end{array}$ & $\begin{array}{c}0.69 \pm \\
0.35\end{array}$ & $\begin{array}{c}1.00 \pm \\
0.00\end{array}$ & $\begin{array}{c}0.84 \pm \\
0.17\end{array}$ & $\begin{array}{c}0.93 \pm \\
0.13\end{array}$ & $\begin{array}{c}0.94 \pm \\
0.17\end{array}$ & $\begin{array}{c}0.94 \pm \\
0.17\end{array}$ & $\begin{array}{c}0.94 \pm \\
0.11\end{array}$ \\
\hline 0.97 & $\begin{array}{c}0.94 \pm \\
0.11\end{array}$ & $\begin{array}{c}0.94 \pm \\
0.17\end{array}$ & $\begin{array}{c}0.94 \pm \\
0.17\end{array}$ & $\begin{array}{c}0.94 \pm \\
0.11\end{array}$ & $\begin{array}{c}0.93 \pm \\
0.13\end{array}$ & $\begin{array}{c}0.94 \pm \\
0.17\end{array}$ & $\begin{array}{c}0.94 \pm \\
0.17\end{array}$ & $\begin{array}{c}0.94 \pm \\
0.11\end{array}$ & $\begin{array}{c}0.83 \pm \\
0.18\end{array}$ & $\begin{array}{c}0.69 \pm \\
0.35\end{array}$ & $\begin{array}{c}1.00 \pm \\
0.00\end{array}$ & $\begin{array}{c}0.84 \pm \\
0.17\end{array}$ & $\begin{array}{c}0.97 \pm \\
0.08\end{array}$ & $\begin{array}{c}1.00 \pm \\
0.00\end{array}$ & $\begin{array}{c}0.94 \pm \\
0.17\end{array}$ & $\begin{array}{c}0.97 \pm \\
0.08\end{array}$ \\
\hline 0.99 & $\begin{array}{c}0.94 \pm \\
0.11\end{array}$ & $\begin{array}{c}0.94 \pm \\
0.17\end{array}$ & $\begin{array}{c}0.94 \pm \\
0.17\end{array}$ & $\begin{array}{c}0.94 \pm \\
0.11\end{array}$ & $\begin{array}{c}0.97 \pm \\
0.08\end{array}$ & $\begin{array}{c}1.00 \pm \\
0.00\end{array}$ & $\begin{array}{c}0.94 \pm \\
0.17\end{array}$ & $\begin{array}{c}0.97 \pm \\
0.08\end{array}$ & $\begin{array}{c}0.83 \pm \\
0.18\end{array}$ & $\begin{array}{c}0.69 \pm \\
0.35\end{array}$ & $\begin{array}{c}1.00 \pm \\
0.00\end{array}$ & $\begin{array}{c}0.84 \pm \\
0.17\end{array}$ & $\begin{array}{c}0.97 \pm \\
0.08\end{array}$ & $\begin{array}{c}1.00 \pm \\
0.00\end{array}$ & $\begin{array}{c}0.94 \pm \\
0.17\end{array}$ & $\begin{array}{c}0.97 \pm \\
0.08\end{array}$ \\
\hline
\end{tabular}




\section{References}

1. Siegel, R.L.; Miller, K.D.; Jemal, A. Cancer statistics, 2021. CA A Cancer J. Clin. 2021, 66, 7-30. [CrossRef] [PubMed]

2. Rehman, M.U.; Cho, S.; Kim, J.; Chong, K.T. BrainSeg-Net: Brain Tumor MR Image Segmentation via Enhanced Encoder-Decoder Network. Diagnostics 2021, 11, 169. [CrossRef]

3. Havaei, M.; Davy, A.; Warde-Farley, D.; Biard, A.; Courville, A.; Bengio, Y.; Pal, C.; Jodoin, P.-M.; Larochelle, H. Brain tumor segmentation with Deep Neural Networks. Med. Image Anal. 2017, 35, 18-31. [CrossRef] [PubMed]

4. $\quad$ Isensee, F.; Jäger, P.F.; Full, P.M.; Vollmuth, P.; Maier-Hein, K.H. nnU-net for brain tumor segmentation. In International MICCAI Brainlesion Workshop; Springer: Cham, Switzerland, 2020; pp. 118-132.

5. Zeineldin, R.A.; Karar, M.E.; Coburger, J.; Wirtz, C.R.; Burgert, O. DeepSeg: Deep neural network framework for automatic brain tumor segmentation using magnetic resonance FLAIR images. Int. J. Comput. Assist. Radiol. Surg. 2020, 15, 909-920. [CrossRef]

6. Perrin, S.L.; Samuel, M.S.; Koszyca, B.; Brown, M.P.; Ebert, L.M.; Oksdath, M.; Gomez, G.A. Glioblastoma heterogeneity and the tumour microenvironment: Implications for preclinical research and development of new treatments. Biochem. Soc. Trans. 2019, 47, 625-638. [CrossRef]

7. Golub, T.R.; Slonim, D.K.; Tamayo, P.; Huard, C.; Gaasenbeek, M.; Mesirov, J.P.; Coller, H.; Loh, M.L.; Downing, J.R.; Caligiuri, M.A.; et al. Molecular Classification of Cancer: Class Discovery and Class Prediction by Gene Expression Monitoring. Science 1999, 286, 531-537. [CrossRef]

8. Leung, Y.F.; Cavalieri, D. Fundamentals of cDNA microarray data analysis. Trends Genet. 2003, 19, 649-659. [CrossRef] [PubMed]

9. Flores, M.; Hsiao, T.-H.; Chiu, Y.-C.; Chuang, E.Y.; Huang, Y.; Chen, Y. Gene Regulation, Modulation, and Their Applications in Gene Expression Data Analysis. Adv. Bioinform. 2013, 2013, 1-11. [CrossRef] [PubMed]

10. Friedman, J.H. Stochastic gradient boosting. Comput. Stat. Data Anal. 2002, 38, 367-378. [CrossRef]

11. Bergstra, J.; Komer, B.; Eliasmith, C.; Yamins, D.; Cox, D. Hyperopt: A Python library for model selection and hyperparameter optimization. Comput. Sci. Discov. 2015, 8, 014008. [CrossRef]

12. De Jay, N.; Papillon-Cavanagh, S.; Olsen, C.; El-Hachem, N.; Bontempi, G.; Haibe-Kains, B. mRMRe: An R package for parallelized mRMR ensemble feature selection. Bioinformatics 2013, 29, 2365-2368. [CrossRef] [PubMed]

13. Rehman, M.U.; Cho, S.; Kim, J.H.; Chong, K.T. BU-Net: Brain Tumor Segmentation Using Modified U-Net Architecture. Electronics 2020, 9, 2203. [CrossRef]

14. Pei, L.; Vidyaratne, L.; Rahman, M.; Iftekharuddin, K.M. Context aware deep learning for brain tumor segmentation, subtype classification, and survival prediction using radiology images. Sci. Rep. 2020, 10, 1-11. [CrossRef] [PubMed]

15. Bashir, S.; Qamar, U.; Khan, F.H. Heterogeneous classifiers fusion for dynamic breast cancer diagnosis using weighted vote based ensemble. Qual. Quant. 2015, 49, 2061-2076. [CrossRef]

16. Kumar, M.; Rath, S. Classification of microarray using MapReduce based proximal support vector machine classifier. Knowl.-Based Syst. 2015, 89, 584-602. [CrossRef]

17. Jain, I.; Jain, V.K.; Jain, R. Correlation feature selection based improved-Binary Particle Swarm Optimization for gene selection and cancer classification. Appl. Soft Comput. 2018, 62, 203-215. [CrossRef]

18. Pradana, A.C.; Aditsania, A. Implementing binary particle swarm optimization and C4.5 decision tree for cancer detection based on microarray data classification. J. Physics: Conf. Ser. 2019, 1192, 012014. [CrossRef]

19. Shukla, A.K.; Tripathi, D. Detecting biomarkers from microarray data using distributed correlation based gene selection. Genes Genom. 2020, 42, 449-465. [CrossRef] [PubMed]

20. Sampathkumar, A.; Rastogi, R.; Arukonda, S.; Shankar, A.; Kautish, S.; Sivaram, M. An efficient hybrid methodology for detection of cancer-causing gene using CSC for micro array data. J. Ambient. Intell. Humaniz. Comput. 2020, 11, 4743-4751. [CrossRef]

21. Kilicarslan, S.; Adem, K.; Celik, M. Diagnosis and classification of cancer using hybrid model based on ReliefF and convolutional neural network. Med. Hypotheses 2020, 137, 109577. [CrossRef] [PubMed]

22. Naser, M.A.; Deen, M.J. Brain tumor segmentation and grading of lower-grade glioma using deep learning in MRI images. Comput. Biol. Med. 2020, 121, 103758. [CrossRef] [PubMed]

23. Lee, J.; Choi, I.Y.; Jun, C.-H. An efficient multivariate feature ranking method for gene selection in high-dimensional microarray data. Expert Syst. Appl. 2021, 166, 113971. [CrossRef]

24. Zexuan Zhu, Y.S. Markov Blanket-Embedded Genetic Algorithm for Gene Selection. Available online: http://csse.szu.edu.cn/ staff/zhuzx/Datasets.html (accessed on 12 May 2020).

25. Ramey, J. Datamicroarray. Available online: https://github.com/ramhiser/datamicroarray/blob/master/inst/data_scripts/ singh-2002/1-download.r (accessed on 18 October 2021).

26. Smith, A. GEO DataSets. (N. L. Medicine, Editor). Available online: https://www.ncbi.nlm.nih.gov/gds (accessed on 21 March 2021).

27. Street, N. Datasets.php. Available online: https:/ / archive.ics.uci.edu/ml/index.php (accessed on 7 June 2021).

28. Jamil, L.S. Data analysis based on data mining algorithms using weka workbench. Int. J. Eng. Sci. Res. Technol. 2016. [CrossRef]

29. Statnikov, A.; Tsamardinos, I.; Dosbayev, Y.; Aliferis, C.F. GEMS: A system for automated cancer diagnosis and biomarker discovery from microarray gene expression data. Int. J. Med Inform. 2005, 74, 491-503. [CrossRef] [PubMed]

30. Scott, L.; Pomeroy, P.; Tamayo, P.; Michelle, G. Prediction of central nervous system embryonal tumour outcome based on gene expression: Letters to nature. Nature 2002, 415, 436-442. 
31. Dennis, G.; Sherman, B.T.; Hosack, D.A.; Yang, J.; Gao, W.; Lane, H.C.; Lempicki, R.A. DAVID: Database for annotation, visualization, and integrated discovery. Genome Biol. 2003, 4, 1-11. [CrossRef]

32. Qu, Y.; Li, R.; Deng, A.; Shang, C.; Shen, Q. Non-unique decision differential entropy-based feature selection. Neurocomputing 2019, 393, 187-193. [CrossRef]

33. Zhou, Z.H. Ensemble Methods: Foundations and Algorithms; CRC Press: Boca Raton, FL, USA, 2012.

34. Dong, X.; Yu, Z.; Cao, W.; Shi, Y.; Ma, Q. A survey on ensemble learning. Front. Comput. Sci. 2020, 14, 241-258. [CrossRef]

35. Chen, T.; Guestrin, C. Xgboost: A scalable tree boosting system. In Proceedings of the 22nd acm sigkdd international conference on knowledge discovery and data mining, New York, NY, USA, 13-17 August 2016; pp. 785-794.

36. Dorogush, A.V.; Ershov, V.; Gulin, A. CatBoost: Gradient boosting with categorical features support. arXiv 2018, arXiv:1810.11363.

37. Ding, C.; Peng, H. Minimum redundancy feature selection from microarraygene expression data. J. Bioinform. Comput. Biol. 2005, 3, 185-205. [CrossRef] [PubMed]

38. Nema, S.; Dudhane, A.; Murala, S.; Naidu, S. RescueNet: An unpaired GAN for brain tumor segmentation. Biomed. Signal Process. Control. 2020, 55, 101641. [CrossRef]

39. Hosack, D.A.; Dennis, G., Jr.; Sherman, B.T.; Lane, H.C.; Lempicki, R.A. Identifying biological themes within lists of genes with EASE. Genome Biol. 2003, 4, R70. [CrossRef] [PubMed] 